Review

\title{
Ursolic Acid-A Pentacyclic Triterpenoid with a Wide Spectrum of Pharmacological Activities
}

\author{
Łukasz Woźniak *, Sylwia Skąpska and Krystian Marszałek \\ Received: 3 July 2015 ; Accepted: 23 September 2015 ; Published: 19 November 2015 \\ Academic Editor: Fernando Albericio \\ Department of Fruit and Vegetable Product Technology, Institute of Agricultural and Food Biotechnology, \\ 36 Rakowiecka Street, 02-532 Warsaw, Poland; skapska@ibprs.pl (S.S.); marszalek@ibprs.pl (K.M.) \\ * Correspondence: lukasz.wozniak@ibprs.pl; Tel.: +48-226-063-604; Fax: +48-228-490-426
}

\begin{abstract}
Ursolic acid (UA) is a natural terpene compound exhibiting many pharmaceutical properties. In this review the current state of knowledge about the health-promoting properties of this widespread, biologically active compound, as well as information about its occurrence and biosynthesis are presented. Particular attention has been paid to the application of ursolic acid as an anti-cancer agent; it is worth noticing that clinical tests suggesting the possibility of practical use of UA have already been conducted. Amongst other pharmacological properties of UA one can mention protective effect on lungs, kidneys, liver and brain, anti-inflammatory properties, anabolic effects on skeletal muscles and the ability to suppress bone density loss leading to osteoporosis. Ursolic acid also exhibits anti-microbial features against numerous strains of bacteria, HIV and HCV viruses and Plasmodium protozoa causing malaria.
\end{abstract}

Keywords: ursolic acid; anticancer; triterpene; anti-inflammatory; antibacterial

\section{Introduction}

Ursolic acid ( $3 \beta$-hydroxy-urs-12-ene-28-oic acid, UA, Figure 1) is a pentacyclic terpenoid exhibiting a wide range of pharmaceutical properties. Ursolic acid is a secondary plant metabolite, usually present in the stem bark, leaves or fruit peel. The health promoting activities of this compound have been unknowingly used for centuries-as an ingredient of herb extracts employed in folk medicine. In recent years researchers, looking for natural biologically active substances, came back to this source of knowledge acquired over generations.

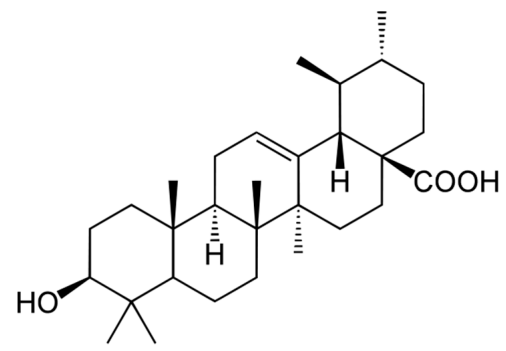

Figure 1. Structure of ursolic acid.

This review is an attempt to describe the present state of knowledge about the pharmacological properties of ursolic acid. Some of the biological activities of this compound have been reviewed before, but these papers were focused on singular aspects [1-4] or rapidly became dated due to the immense interest in the features of UA in recent years [5-7]. 


\section{Natural Occurrence and Biosynthesis of Ursolic Acid}

Ursolic acid and related triterpene compounds like oleanolic acid, betulinic acid, uvaol or $\alpha$ and $\beta$-amyrin are widespread in plants. Their content and composition differs between various species, due to the presence and activity of the enzymes responsible for their synthesis. Amongst plants matrices with a high content of ursolic acid and of potentially practical significance as a source of this compound one can mention apple (Malus domestica) fruit peel, marjoram (Origanum majorana) leaves, oregano (Origanum vulgare) leaves, rosemary (Rosmarinus officinalis) leaves, sage (Salvia officinalis) leaves, thyme (Thymus vulgaris) leaves, lavender (Lavandula angustifolia) leaves and flowers, eucalyptus (Eucalyptus) leaves and bark, black elder (Sambucus nigra) leaves and bark, hawthorn (Crataegus spp.) leaves and flowers, coffee (Coffea arabica) leaves and the wax layer of many edible fruits $[8,9]$.

The biosynthesis of ursolic acid and related compounds in plant tissues should be considered as a three phase process. The first stage is the production of isopentenyl diphosphate (IPP) which is a five-carbon building block utilized to create all terpenic compounds. For many years it has been believed that the mevalonate pathway (MVA) is the exclusive source of this compound. In this cytosol-carried metabolic pathway two molecules of Acetyl-CoA (created in the citric acid cycle) are transformed to one molecule of IPP through a six stage process. Recent investigations have discovered another route, the deoxyxylulose/methylerythritiol phosphate (DXP) pathway. In this plastid-located process isopentyl diphosphate is synthesized from pyruvate and glyceraldehyde-3-phosphate (Figure 2). Synthesis of triterpenes in the plastid is impossible due to the lack of necessary enzymes, however the possibility of cross-talk between the two presented pathways is considered $[10,11]$.

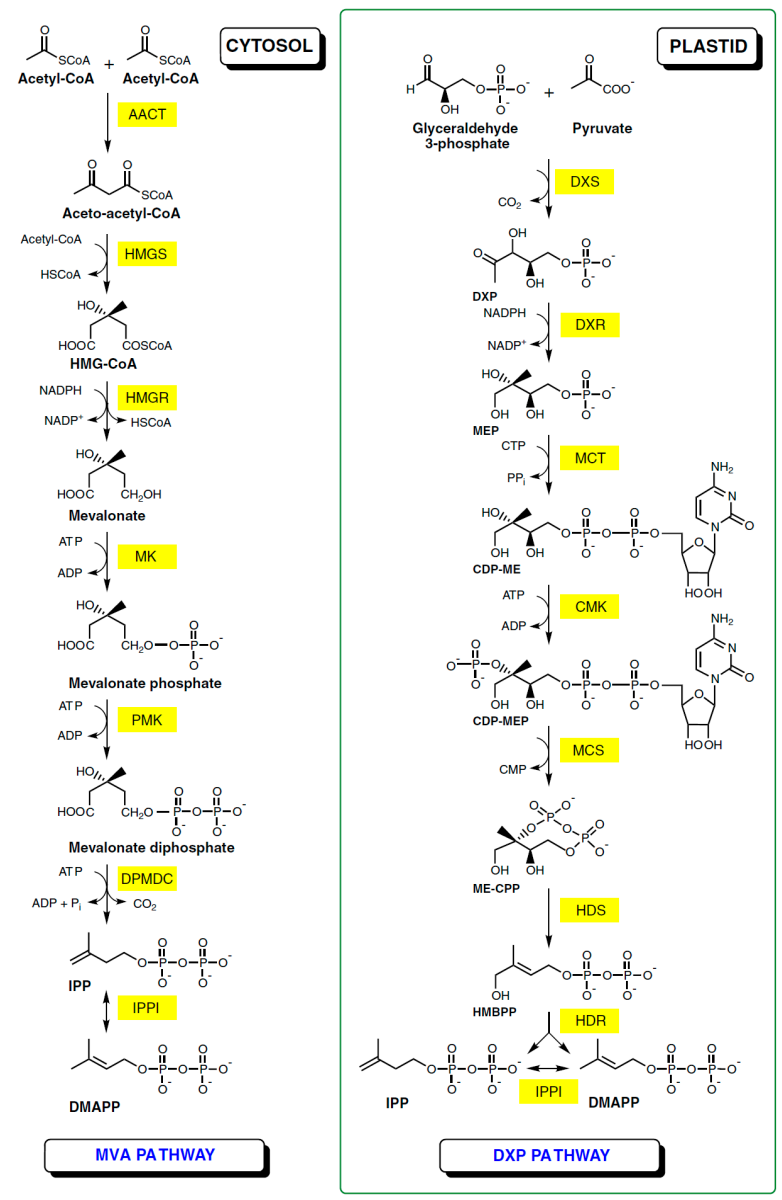

Figure 2. IPP formation by the MPA and DXP pathways [12]. 
The second stage of UA production is synthesis of 2,3-oxidosqualene and its cyclisation leading to formation of $\alpha$-amyrin. Molecules of IPP and its isomer dimethylallyl diphosphate (DMAPP) are used to create squalene (through the intermediates geranyl pyrophosphate and farnesyl pyrophosphate). Then squalene epoxidase oxidizes this compound to 2,3-oxidosqalene. The group of enzymes named oxidosqualene cyclases (OSCs) is responsible for the cyclisation and rearrangement of the terpenoid chain leading to the formation of various scaffolds, including $\alpha$-amyrin [13].

The last stage is modification of $\alpha$-amyrin by group of cytochrome P450 enzymes called $\alpha / \beta$-amyrin 28 -monooxygenases. The methyl group-containing C-28 is oxidized to a carboxyl thus finishing the UA biosynthesis process [13].

\section{Ursolic Acid as a Tool in Cancer Prevention and Therapy}

\subsection{General Review of Literature Data on Ursolic Acid Anti-Cancer Activities}

Ursolic acid is one of the most promising substances of biological origin when it comes to the prevention and therapy of cancer. Novel pharmacological strategies do not rely only on the destruction of tumor cells, but also modulate their metabolism to prevent angiogenesis and metastasis, enforce differentiation of cells and protect healthy tissues against inflammation and oxidative stress that may lead to neoplasm formation.

UA can be described as a multi-tasking agent; it influences several cell signaling enzymes and simultaneously protects it against carcinogenic agents. The summary of the studies describing ursolic acid's impact on carcinomas in vitro and in vivo is shown in Table 1 . While papers reporting protective effects (including anti-inflammatory and antioxidant properties) are listed in Table 2.

It should be noted that in the majority of mentioned works the authors were testing pure compounds or attributed therapeutic properties to ursolic acid. There are also numerous studies describing the effects of plant extract without assigning the activity to a particular compound; the authors did not include them in this work.

\subsection{Cellular Signaling Pathways and Enzyme Inhibition-The Key to the Ursolic Acid Activity against Cancer}

To fully understand modus operandi of anti-cancer drugs one must take a closer look at cell signaling. This very complex system of communication coordinates all cellular activities and responses on extracellular signals. The schematic diagram of the main intracellular signal routes is presented in Figure 3.

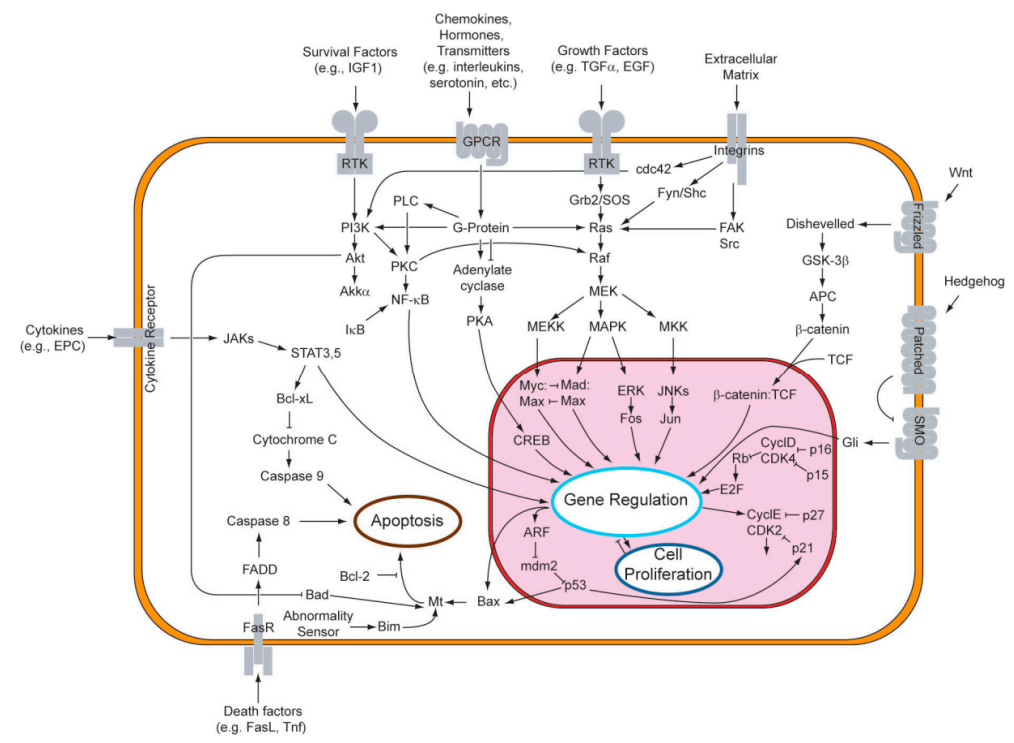

Figure 3. Main intracellular signaling pathways. From: Wikipedia. Wikimedia Foundation, Inc. 
Table 1. Ursolic acid in cancer therapy.

\begin{tabular}{|c|c|c|}
\hline Carcinoma Type & Model Used & Mechanism of Action \\
\hline bladder cancer & cell lines (NTUB1 and T24) & $\begin{array}{l}\text { - induction of apoptosis: } \\
\text { (i) using endoplasmic reticulum stress response to activate c-Jun N-terminal kinase signaling [14] } \\
\text { (ii) connected with reactive oxygen species production [15] }\end{array}$ \\
\hline & rodent model (mice) & - inhibition of tumor growth and induction of apoptosis by modulation of PI3K/Akt/mTOR pathway signaling [16] \\
\hline breast cancer & $\begin{array}{c}\text { cell lines (MCF-7, MCF-7/ADR } \\
\text { and MDA-MB-231) }\end{array}$ & $\begin{array}{l}\text { - inhibition of growth [17] } \\
\text { - antiproliferative activity [18] } \\
\text { - suppression of migration and metastasis by modulating c-Jun N-terminal kinase (JNK), Akt and mTOR signaling [19] } \\
\text { induction of apoptosis: } \\
\text { (i) via mitochondrial death pathway and extrinsic death receptor pathway [20] } \\
\text { (ii) by suppressing expression of FoxM1 protein [21] } \\
\text { - cytotoxicity [22] }\end{array}$ \\
\hline cervical cancer & cell lines (HeLa and SiHa) & $\begin{array}{l}\text { - inhibition of proliferation }[23,24] \\
\text { - induction of apoptosis through mitochondrial intrinsic pathway and suppression of ERK1/2 MAPK pathway [25] } \\
\text { - enhancement of chemotherapeutic efficiency [26] } \\
\text { - cytotoxicity }[22,27]\end{array}$ \\
\hline colorectal cancer & $\begin{array}{l}\text { cell lines (Caco-2, CO115, } \\
\text { CT26, DLD1, HCT15, HCT116, } \\
\text { HT29, SW480 and SW620) }\end{array}$ & $\begin{array}{l}\text { - inhibition of proliferation }[17,18,28-30] \\
\text { - induction of apoptosis: } \\
\text { (i) via downregulation of Bcl-2, Bcl-xL and survivin activity [17] } \\
\text { (ii) by influencing PI3K signaling pathway [28] } \\
\text { (iii) via p53-independent upregulation of death receptors [31,32] } \\
\text { (iv) by autophagy through JNK pathway [33] } \\
\text { - through cyclooxygenase } 2 \text { (COX-2) pathway [34] } \\
\text { - enhancement of ionizing radiation-induced apoptotic effect [35] } \\
\text { - cytotoxicity [36] }\end{array}$ \\
\hline fibrosarcoma & cell lines (HT1080) & - suppression of metastasis by downregulation of matrix metallopeptidase 9 (MMP-9) [37] \\
\hline
\end{tabular}


Table 1. Cont.

\begin{tabular}{|c|c|c|}
\hline Carcinoma Type & Model Used & Mechanism of Action \\
\hline gastric cancer & $\begin{array}{l}\text { cell lines (AGS, BGC823, } \\
\text { SGC7901 and SNU-484) }\end{array}$ & $\begin{array}{l}\text { - induction of apoptosis: } \\
\text { (i) via downregulation of Bcl-2 [38] } \\
\text { (ii) by activation of caspase-3, -8, and -9 and downregulation of Bcl-2 expression [39] } \\
\text { (iii) through inhibition of cyclooxygenase } 2 \text { [40] } \\
\text { - cytotoxicity [22,36] } \\
\text { - suppression of proliferation [24] }\end{array}$ \\
\hline & rodent model (rats) & - inhibition of metastasis through suppressing association of ZIP/p62 with PKC- $\zeta$ and downregulation of MMP-9 [41] \\
\hline glioma & cell lines (1321N1, U87 and U251) & $\begin{array}{l}\text { - inhibition of proliferation and induction of apoptosis by suppression of TGF- } \beta 1 / \mathrm{miR}-21 / \text { PDCD4 pathway [42] } \\
\text { - promotion of differentiation by inhibition of the endogenous reverse transcriptase (RT) [43] } \\
\text { - suppression of growth via reactive oxygen species accumulation [44] }\end{array}$ \\
\hline \multirow{4}{*}{ hepatic cancer } & rodent model (mice) & $\begin{array}{l}\text { - suppression of AMF/PGI mediated tumorigenic activities [45] } \\
\text { - inhibition of proliferation and induction of apoptosis by downregulation of cyclooxygenase-2 (COX-2) [46] }\end{array}$ \\
\hline & & $\begin{array}{l}\text { - antiproliferative activity }[18,24,47] \\
\text { - induction of apoptosis: }\end{array}$ \\
\hline & $\begin{array}{c}\text { cell lines } \\
\text { (H22, Hep3B, HepG2 and Huh7) }\end{array}$ & $\begin{array}{l}\text { (i) by activation of caspase- }-3,-8 \text {, and }-9 \text { and downregulation of Bcl-2 expression [19] } \\
\text { (ii) through downregulation of XIAP and mitochondrial-dependent pathway [48] } \\
\text { (iii) via downregulation of survivin and activation of caspase-3 through PI3K/Akt/mTOR pathway [49] }\end{array}$ \\
\hline & & $\begin{array}{l}\text { - antiangiogenic properties [50] } \\
\text { - cytotoxicity [36] }\end{array}$ \\
\hline \multirow[b]{2}{*}{ melanoma } & rodent model (mice) & - antiangiogenic properties by changing matrix metalloproteinases activity [51] \\
\hline & $\begin{array}{l}\text { cell lines } \\
\text { (A375, B16F10 and M4Beu) }\end{array}$ & $\begin{array}{l}\text { - induction of apoptosis: } \\
\text { (i) through mitochondrial intrinsic pathway and caspase-3 activation [52] } \\
\text { (ii) by activation of p53 and caspase-3 gene expression and suppression of NF-kB mediated activation of Bcl-2 [53] } \\
\text { (ii) through mitochondrial pathway [54] } \\
\text { - inhibition of proliferation and promotion of differentiation by suppression of the endogenous reverse transcriptase (RT) [43] } \\
\text { - enhancement of ionizing radiation-induced apoptotic effect [31] }\end{array}$ \\
\hline
\end{tabular}


Table 1. Cont.

\begin{tabular}{|c|c|c|}
\hline Carcinoma Type & Model Used & Mechanism of Action \\
\hline leukemia & $\begin{array}{c}\text { cell lines } \\
\text { (Jurkat, HL60, HL60/ADR, K562, } \\
\text { K562/ADR, THP1 and U937) }\end{array}$ & $\begin{array}{l}\text { - induction of apoptosis: } \\
\text { (i) through downregulation of ezrin [55] } \\
\text { (ii) via upregulation of PTEN gene expression and inactivation of PI3K/Akt/mTOR pathway [56] } \\
\text { (iii) by inactivation of PKB as well as activation of JNK [57] } \\
\text { - involving enhanced intracellular Ca2+ signals [58] } \\
\text { - inhibition of growth [17] } \\
\text { - inhibition of proliferation [23] } \\
\text { - induction of differentiation by ERK1/2 MAPK pathway activation [59] } \\
\text { - cytotoxicity [22] }\end{array}$ \\
\hline lung cancer & $\begin{array}{c}\text { cell lines } \\
\text { (A549, ASTC-a-1, Calu-6, H640 } \\
\text { and H3255) }\end{array}$ & $\begin{array}{l}\text { - inhibition of proliferation }[23,60] \\
\text { - inhibition of metastasis by suppressing expression of AEG-1 and inhibition of NF- } \mathrm{kB} \text { [61] } \\
\text { - enhancement of chemotherapeutic effect [26] } \\
\text { - induction of apoptosis by upregulation of matrix metalloproteinase and activation of caspase-3 [62] }\end{array}$ \\
\hline lymphoma & cell lines (Daudi) & - induction of apoptosis [63] \\
\hline multiple myeloma & $\begin{array}{c}\text { cell lines } \\
\text { (U266, RPMI and 8226.MM1.S) }\end{array}$ & $\begin{array}{l}\text { - suppression of proliferation and chemosensitization, inhibition of STAT3 activation pathway by expression of tyrosine } \\
\text { phosphatase SHP-1 protein [64] }\end{array}$ \\
\hline neuroblastoma & cell lines (IMR32 and SH-SY5Y) & - inhibition of proliferation $[23,24]$ \\
\hline ovarian cancer & cell lines (CAOV and SK-OV-3) & $\begin{array}{l}\text { - inhibition of proliferation by suppressing ERK activity and expression of ERK } 1 / 2 \text { [65] } \\
\text { - induction of apoptosis: } \\
\text { (i) by upregulation of BAX (Bcl-2-like protein } 4 \text { ) expression and downregulation of Bcl-2 expression [65] } \\
\text { (ii) by activation of caspases and phosphorylation of GSK3 beta [66] }\end{array}$ \\
\hline pancreatic cancer & $\begin{array}{l}\text { cell lines (AsPC-1, Capan-1, } \\
\text { MIA, Paca-1 and PANC-2) }\end{array}$ & $\begin{array}{l}\text { - induction of apoptosis: } \\
\text { (i) with upregulation of p53, p21(waf1) and Noxa proteins levels [67] } \\
\text { (ii) by induction of JNK pathway and suppression of PI3K/Akt/NF-kB pathway [68] }\end{array}$ \\
\hline
\end{tabular}


Table 1. Cont.

\begin{tabular}{|c|c|c|}
\hline Carcinoma Type & Model Used & Mechanism of Action \\
\hline \multirow[b]{2}{*}{ prostate cancer } & rodent model (mice) & $\begin{array}{l}\text { - suppression of metastasis by inhibition of CXCR4/CXCL12 signaling [69] } \\
\text { - suppression of growth by downregulation expression of cyclin D1 and COX-2 and upregulation of caspase-3 levels [70] }\end{array}$ \\
\hline & $\begin{array}{l}\text { cell lines } \\
\text { (DU145, LNCaP and PC3) }\end{array}$ & $\begin{array}{l}\text { - induction of apoptosis: } \\
\text { (i) through activation of caspases and downregulation of c-IAPs [71] } \\
\text { (ii) through autophagy [72] } \\
\text { (iii) via activation of JNK and inhibition of Akt pathways [73] } \\
\text { (iv) through cyclooxygenase } 2 \text { (COX-2) pathway [34] } \\
\text { (v) by activation of JNK-induced Bcl-2 phosphorylation and degradation [74] } \\
\text { (vi) by downregulation of Bcl-2 [75] } \\
\text { - enhancement of ionizing radiation-induced apoptotic effect [31] } \\
\text { - cytotoxicity [36] }\end{array}$ \\
\hline thyroid cancer & cell lines (ARO) & - inhibition of proliferation and promotion of differentiation by inhibition of the endogenous reverse transcriptase (RT) [43] \\
\hline
\end{tabular}


Table 2. Ursolic acid in cancer prevention.

\begin{tabular}{|c|c|c|}
\hline Preventive Effect & Model Used & Mechanism of Action \\
\hline anti-inflammatory & $\begin{array}{l}\text { mouse primary splenocytes } \\
\text { activated T cells, B cells and macrophages; mice } \\
\text { rat edema tests } \\
\text { mice } \\
\text { human intestinal epithelial cells and peritoneal } \\
\text { macrophages from mice } \\
\text { rat mast cells } \\
\text { murine peritoneal macrophages } \\
\text { PC12 cells } \\
\text { oedema in mice } \\
\text { pleurisy in mice } \\
\text { phagocyte cells } \\
\text { arthritis-induced mice } \\
\text { Th17 cells } \\
\text { biochemical assays }\end{array}$ & $\begin{array}{l}\text { inhibition of Th2 cytokines production [76] } \\
\text { suppression of NF- } \mathrm{kB} \text {, AP-1 and NF-AT activity [77] } \\
\text { unclear, probably connected with glucocorticoids [78] } \\
\text { reductions of Th2 cytokines and ovalbumin-specific IgE production, and eosinophil infiltration via the } \\
\text { Th2-GATA-3, STAT6, and IL-17-NF- } \mathrm{k} B \text { pathways [79] } \\
\text { inhibition of production of pro-inflammatory cytokines, IkB } \alpha \text { phosphorylation/degradation and NF- } \mathrm{kB} \text { DNA } \\
\text { binding activity [80] } \\
\text { inhibition of histamine release [81] } \\
\text { suppression of NO production and iNOS expression via downregulation of NF- } \mathrm{kB} \text { activation; attenuation of } \\
\text { expression of COX-2 and the secretion of proinflammatory cytokines like TNF- } \alpha \text { and IL-6 [82] } \\
\text { attenuation of } \mathrm{H}_{2} \mathrm{O}_{2} \text { and MPP-induced release of IL-6 and TNF- } \alpha \text { [83] } \\
\text { attenuation of inflammation [84] } \\
\text { reduction of leukocytes, interleukin-1 beta (IL-1 } 1 \beta \text { ) and tumor necrosis factor-alpha (TNF- } \alpha \text { ) levels [85] } \\
\text { inhibition of histamine release; inhibition of prostaglandins and leukotrienes production [86] } \\
\text { alteration of Th1/Th2 cytokine production [87] } \\
\text { suppression of interleukin-17 production by antagonizing function of ROR } \gamma \mathrm{t} \text { protein [88] } \\
\text { inhibition of cyclooxygenase-2 catalyzed prostaglandin biosynthesis [89] }\end{array}$ \\
\hline anti-oxidative & $\begin{array}{l}\text { PC12 cells } \\
\text { rat liver microsomes } \\
\text { RAW247 cells } \\
\text { isolated rat heart mitochondria } \\
\text { human blood lymphocytes } \\
\text { Caco-2 cells }\end{array}$ & $\begin{array}{l}\text { attenuation of } \mathrm{H}_{2} \mathrm{O}_{2} \text { and MPP-induced impairment in catalase and superoxide dismutase activity [83] } \\
\text { protection against lipid peroxidation [90] } \\
\text { inhibition of NO production [91] } \\
\text { decrease in } \mathrm{H}_{2} \mathrm{O}_{2} \text { production in the mitochondria [92] } \\
\text { normalization of antioxidant levels; reduction of lipid peroxidation [93] } \\
\text { protection of DNA against oxidative damage [94] }\end{array}$ \\
\hline chemical-induced cancer & $\begin{array}{l}\text { mouse skin } \\
\text { rats } \\
\text { rats } \\
\text { human bronchial epithelial cells and mice }\end{array}$ & $\begin{array}{l}\text { inhibition of binding benzo(a)pyrene and 7,12-dimethylbenz(a)anthracene to DNA [95] } \\
\text { suppression of preneoplastic lesions formation by 1,2-dimethylhydrazine [96] } \\
\text { inhibition of formation of aberrant crypt foci by azoxymethane [97] } \\
\text { inhibition of tobacco smoke extract-induced cell injury [98] }\end{array}$ \\
\hline radiation-induced cancer & mice & enhancement of hematopoietic system recovery [99] \\
\hline ROS-induced cancer & $\begin{array}{l}\text { murine } \mathrm{T} \text { cells } \\
\text { rats } \\
\text { keranocite cell line and mice }\end{array}$ & $\begin{array}{l}\text { inhibition of cell activation through modulation of NF- } \mathrm{kB} \text { signaling [100] } \\
\text { attenuation of hepatocellular carcinoma induction by diethylnitrosamine-induced reactive oxygen species [101] } \\
\text { skin cancer prevention; protection against hydrogen peroxide induced DNA damage [102] }\end{array}$ \\
\hline viral-induced cancer & Raji cell line and mice & inhibition of Epstein-Barr virus activation induced by 12-O-tetradecanoylphorbol-13-acetate (TPA) [103-105] \\
\hline
\end{tabular}


The anticancer activity of ursolic acid is associated with its ability to influence the activity of several enzymes. Therefore it is able to modulate processes occurring inside tumor cells activating routes leading to cell death (usually by apoptosis) and suppressing ones leading to the proliferation, growth and migration of cancer.

\subsubsection{Signaling Pathways}

The MAPK/ERK and PI3K/AKT/mTOR signaling cascades play critical roles in the transmission of signals from growth factor receptors to regulate gene expression. Both these pathways are responsible for anti-apoptotic and drug resistance effects in cells [106]. The ability to suppress communication through these routes is one of the most important anti-cancer activities of UA. It has been reported by numerous research teams in various tumor types.

High expectations are also surrounding UA impact on nuclear factor $\kappa B$. Activity of NF- $\mathrm{kB}$ is connected with reaction on such stimuli as cytokines, free radicals or antigens, and it plays crucial role in immunologic answer against infection. Malignant cells are characterized by abnormally high activity of this transcription factor, what leads to intense proliferation and make NF- $\mathrm{kB}$ one of the main targets of modern oncotherapy [107]. Capability to lower activity of NF-kB has been noticed not only by oncologist but also scientists dealing with bone and brain issues.

\subsubsection{FOXM1 Transcription Factor}

Forkhead box (FOX) proteins are family of transcription factors playing crucial role in regulating expression of genes involved in cell growth. FOXM1 has been recognized as exceptional important as its aberrant upregulation might be inducing genomic instability and leading to malignant transformation [108]. FOXM1 has been already used as biomarker of early stages of cancer. This protein has been also shown to possess ability to cross-talk with other molecules playing role in cancer development (like: NF-kB, COX-2, ERK and MMPs) [109]. Inhibition of Forkhead box M1 expression by UA has been reported by Wang et al. [21] in their study on MCF-7 human breast cancer cells.

\subsubsection{Apoptosis Regulating Proteins}

Apoptosis is the process of programmed cell death occurring as a result of activation of the specific cellular pathways. In contrast to necrosis, this process is highly regulated and leads to chromosomal DNA fragmentation. The induction of apoptosis by various agents is an important part of modern cancer therapies. Unfortunately apoptosis in cancer cells is often blocked by the activity of mutated genes regulating the cell cycle. Therefore different steps of the apoptotic process should be targeted to bypass such blocks [1].

Apoptosis induction is the uppermost anti-cancer activity of ursolic acid. It has been reported in dozens of papers, as regards several cancer types, both in vitro and in vivo. This aptitude is often connected with the Bcl-2 apoptosis regulators activity. This group of evolutionarily related proteins consist of both pro- and anti-apoptotic agents and is regarded as crucial in regulation of cell death through intrinsic apoptotic pathway [110]. Ursolic acid is able to change activity of three amongst 25 members of this family: anti-apoptotic proteins Bcl-2 and Bcl-xL are suppressed, while pro-apoptotic BAX activity is enhanced $[17,19,38,39,65]$.

Caspases are family of cysteine proteases playing essential role in apoptosis. They are final step of cell death pathways and are responsible for e.g., DNA fragmentation, cleavage of nuclear proteins and as a result blebbing and cell death [111]. Inhibitors of apoptosis proteins (IAPs) are a family of functionally and structurally related proteins which are able to bind caspases and consequently prevent apoptosis of cell. Overexpression of these compounds can be responsible for drug resistance of neoplasm cells and its inhibition became one of the therapeutic targets in cancer treatment [112]. Ursolic acid exhibits ability to reduce expression of proteins from IAP family. Amongst influenced molecules researchers mentioned XIAP [48], c-IAPs [71] and survivin [17,49]. 


\subsubsection{Endogenous Reverse Transcriptase}

Sequencing of the human genome shown that retrotransposable elements make up about $45 \%$ of the human DNA. Almost all of these elements contain genes responsible for reverse transcriptase (RT) coding. In most tissues expression of RT-coding genes is very low, however high expression is distinctive for undifferentiated cells like embryos, germ cells or tumor cells. Sciamanna et al. [113] revealed that RT inhibitors had been able to reduce cell proliferation and induce morphological differentiation in four carcinoma lines. They also connected RT activity with control of proliferation and differentiation in neoplastic cells.

Role of ursolic endogenous reverse transcriptase as a mediator of ursolic acid properties was reported by Bonaccorsi et al. [43]. Their work confirmed ability of UA to suppress growth and induce differentiation in cancer cells; it also shown that ursolic acid exhibited RT inhibiting activity and connected it with anti-tumor activities.

\subsubsection{Factors Involved in Metastasis and Angiogenesis}

Angiogenesis is the formation of new blood vessels from other pre-existent ones during development, growth, wound repair or the female reproductive cycle. Angiogenesis is one of cancer's hallmarks since it is required for both tumor progression and dispersal of metastatic cells. This resulted in the fact that the inhibition of angiogenesis has become an alternative therapeutic approach to cancer therapy. The angiogenic process is activated by intracellular signals that activate resting endothelial cells, which are stimulated to release degrading enzymes allowing endothelial cells to migrate, proliferate, and finally differentiate to form new vessels. Any of these steps might be a potential target for pharmacological compounds [114].

Anti-angiogenic properties of ursolic acid are usually attributed to inhibition of the downregulation of matrix metalloproteinases activity. Metalloproteinases are group of the enzymes involved in degradation of extracellular matrix. Their activity in tumor tissues is elevated due to increased demand for oxygen and glucose of neoplasm. UA inhibiting activity against MMP-9 has been confirmed by several research teams, however activity against MMP-2 remains subject of discussion: Huang et al. [62] reported that UA is able to suppress MMP-2 expression while Cha et al. [37] did not observe such an effect in their study.

\subsubsection{Cyclooxygenase-2 (COX-2)}

The connection between inflammation and cancer had been suggested as early as in 1863 by Rudolf Virchow. Currently chronic inflammation, with concomitant activity of cytokines and increased production of reactive oxygen species, is recognized as a cancerogenesis-promoting condition [115]. The cyclooxygenases are enzymes responsible for conversion of arachidonic acid to prostaglandin $\mathrm{H} 2$, which is precursor of other prostanoids. Their inhibitors (e.g., acetylsalicylic acid, ibuprofen, naproxen) are often used as anti-inflammatory drugs and painkillers [116]. Ursolic acid proved to be efficient COX-2 inhibitor able to suppress inflammation progress [80,86]. Additionally lowering activity of this cyclooxygenase has been correlated with caspase-3 activity and affected apoptosis rate in cancer cells $[40,46]$.

\subsection{Protection against Tumor-Inducing Agents}

Several tests of the anti-carcinogenic activity of ursolic acid against different induction sources have been conducted. These test included chemical agents (such as benzo(a)pyrene, azoxymethane and tobacco smoke extract) [95-98], reactive oxygen species producers (such as hydrogen peroxide) [100-102], ionizing radiation [99] and viral pathogens (Epstein-Barr virus) [103-105]. 


\subsection{Ursolic Acid as a Drug-Clinical Trials}

The ultimate goal of every cancer research is the implementation of the compound to clinical use. Currently ursolic acid is undergoing phase I trials to evaluate its safety and adverse effects in patients. Due to poor water solubility and low bioavailability ursolic acid had been administered as a liposomes. So far results of only three such studies have been published [117-119]—all of them were performed in The People's Republic of China. Ursolic acid liposomes showed tolerable toxicity and adverse effects-only one of 108 patients reported third grade adverse activity. The most frequent complaints were nausea, diarrhea and skin problems. The common conclusion of all studies was the necessity of the continuation of research during phase II tests.

\section{Impact of Ursolic Acid on Condition and Functioning of Body Organs}

\subsection{The Liver}

The liver is one of the most important organs of the body. It is responsible for a wide range of metabolic functions, including detoxification of xenobiotics, production of hormones and digestive enzymes, glycoside and fat-soluble vitamins storage and the decomposition of red blood cells. Due to its strategic location and multidimensional functions the liver is prone to many diseases, like hepatitis, hepatic steatosis, cirrhosis, cholelithiasis and drug-induced liver damage. Fortunately liver is the only internal organ capable to regenerate-as little as $25 \%$ of the original mass can reconstruct its full size.

Ursolic acid showed good protective activity against a wide range of liver-threatening substances. Saraswat et al. [120] were testing UA isolated from Eucalyptus tereticornis extract against ethanol toxicity in isolated rat hepatocytes. They found that this triterpene was able to decrease the loss of hepatocyte viability by as much as $76 \%$. A similar problem has been studied by Saravanan et al. [121], this time however in vivo using alcohol-administered rats. They reported that UA increased the level of circulatory antioxidants and serum protein and decreased the total bilirubin level and lipid peroxidation markers. Histopathological observations were in correlation with biochemical parameters. Paracetamol and tetrachloride were other liver-intoxicating agents tested by Shukla et al. [122] and Martin-Aragón et al. [123], respectively. Both these papers revealed increase of hepatocytes viability and improvement of serum markers in UA treated samples.

The impact of UA on metabolic disorders in high fat diet-fed mice and rats was surveyed in research conducted by Sundaresan et al. [124] and Li et al. [125]. The first group focused on hepatic lipid accumulation and noticed that the combined treatment of UA and rosiglitazone (an antidiabetic drug in the thiazolidinedione class) significantly reduced the hepatic marker enzyme activities and decreased the lipid accumulation in the liver. Furthermore, combination treatment downregulated lipogenic genes and upregulated fatty acid oxidative genes. The latter team discovered that UA effectively ameliorated high fat diet-induced hepatic steatosis through a PPAR- $\alpha$ involved pathway, via improving key enzymes controlling lipid metabolism.

Wang et al. [126] were looking for a possibility to improve hepatic fibrosis patients by UA administration. They performed tests on hepatic stellate cells (HSCs) isolated from rats and found that UA induces apoptosis of these cells, leading to partial amelioration of fibrosis.

Interesting results were acquired by Jin et al. [127]. They discovered that ursolic acid was able to enhance liver regeneration after partial hepactomy in mice. A significant increase in liver to body weight ratio has been observed (compared to control group), along with the stimulation of expression of cyclins and C/EBP proteins.

\subsection{The Heart}

Cardiovascular diseases are the major causes of mortality and morbidity in industrialized countries. They are responsible for about $30 \%$ of all deaths worldwide. Amongst the most common disorders of the cardiovascular system one can mention myocardial infraction (commonly known as heart attack), stroke, atherosclerosis, hypertension and varicose veins. Although not all 
cardiovascular diseases are life threatening, all of them significantly decrease life quality and generate enormous social and financial costs [128].

The first study which reported the impact of UA on the cardiovascular system was conducted by Somova et al. [129]. It revealed that the administration of UA has been able to lower the heart rate of genetically hypertensive rats by $32 \%$.

Further research has been carried out in various directions. Vasorelaxant properties of ursolic acid were investigated by Aguirre-Crespo et al. [130], Rios et al. [131] and Shimada and Inagaki [132]. The first two teams connected the activity of UA with the production and release of nitric oxide (NO) in isolated thoracic aorta and in vivo on Wistar rats, respectively. Shimada and Inagaki focused on the inhibitory effect on angiotensin I-converting enzyme (ACE), which plays an important role in the regulation of blood pressure.

Ursolic acid has been also used as a compound with a potent protective effect in artificially induced (by isoproterenol administration) myocardial infarction. Senthil et al. [133] were testing the level of cardiac markers, lipid peroxidation products, lipid profiles and membrane-bound proteins in the serum of Wistar rats treated with isoproterenol. They found that UA was able to prevent alterations and restore enzyme activity to normal levels indicating cardioprotective activities. These results were confirmed and expanded in two works by Radhiga et al. [134,135]. It was reported that UA had been able to stabilize the level of numerous markers and blood constituents. In addition the anti-apoptotic effect on cardiac muscle cells has been shown. Heart-protective features of UA were also presented in work by Saravanan and Pugalendi [136]. They investigated oxidative stress induced in ethanol-administered rats. Like in the abovementioned papers ursolic acid lowered levels of lipid peroxidation products and increased the activities of free radical scavenging enzymes and antioxidant levels in heart tissue.

Administration with ursolic acid also prevents injuries to blood vessels. Pozo et al. [137] revealed that UA in daily doses of $6 \mathrm{mg} / \mathrm{kg}$ body weight was able to inhibit neointima formation in rats' carotid artery. In the paper by Lv et al. [138] the authors describe the protective effect of UA on the human umbilical vein endothelial cells (HUVECs) damaged by C-reactive protein. They reported that UA inhibited the harmful effect in a dose-dependent manner.

The impact of ursolic acid on atherosclerosis is the subject of dispute amongst scientists since some studies show potentially beneficial effects while others show potentially negative effects [139]. For example Ullevig et al. [140] reported the inhibition of monocyte dysfunction and the slowing down of accelerated atherosclerosis in diabetic mice, while Messner et al. [141] described the stimulation of atherosclerotic plaque formation in mice administered with UA.

The potentially harmful effect of UA intake has been presented by Kim et al. [142]. They discovered that this triterpene is capable to make platelets more susceptible to aggregation, and they should be used with caution by people with a predisposition to cardiovascular events.

\subsection{The Brain}

Excitotoxicity and oxidative stress are two phenomena that have been repeatedly described as being implicated in a wide range of disorders of the nervous system. Such ailments include several common idiopathic neurological diseases, traumatic brain injury, and the consequences of exposure to certain neurotoxic agents. Both excitoxicity and oxidative stress result from the failure of normal compensatory mechanisms to maintain cellular homeostasis and may lead to permanent damaging of the brain and decrease of cognitive functions [143].

The first research focusing on the protective effect of ursolic acid on neurons has been conducted by Shih et al. [144]. Neuronal cultures from rats' hippocampi were treated with kainic acid with and without pretreatment of 5-15 $\mu \mathrm{M}$ ursolic acid. It was observed that UA significantly decreased damage and suppressed free radical generation.

Lu et al. [145] were investigating the protective effect of UA against galactose-induced damage on mice brains. They reported an increase of antioxidant enzymes activity (catalase, superoxide 
dismutases, glutathione peroxidase and glutathione reductase) and linked it with triterpene activity. Furthermore, they found that UA significantly increased the level of the growth-associated protein GAP43. The next paper of this team [146] reported that ursolic acid administration significantly improved the behavioral performance of D-gal-treated mice in the step-through test and the Morris water maze task. The results also showed that UA significantly reduced the number of activated microglia cells and astrocytes, downregulated the expression of NOS and COX-2, and decreased the interleukin and tumor necrosis factor. Moreover, UA significantly inhibited NF-kB nuclear translocation in the prefrontal cortex of galactosis-treated mice.

Suppressing NF-KB by ursolic acid as a method to attenuate cognitive deficits and avoid brain damage has been reported by Wang et al. [147] and Li et al. [148]. Their models were lipo-polysaccharide-damaged mouse brains and mice after cerebral ischemia, respectively.

Wu et al. [149] described another intracellular signaling pathway involved in UA neuroprotective activity. They discovered that UA can activate PI3K/Akt signaling and suppress Forkhead box protein O1 (FoxO1) activity in domoic acid-induced mice. Moreover, UA attenuated the mitochondrial dysfunction and cognitive deficits through promoting Akt phosphorylation and FoxO1 nuclear exclusion in the hippocampus.

The impact of UA on the brain is not limited to the cellular level. Machado et al. [150], encouraged by results acquired during a test utilizing rosemary extract, surveyed the influence of UA on mice behavior. They performed two predictive tests of antidepressant properties: the tail suspension test (TST) and the forced swimming test (FST). The compound increased immobility time in both tests. Further investigation showed that activity of UA was likely mediated by interaction with the dopaminergic system.

Research conducted by Colla et al. [151] confirmed these results using TST and open-field test. Interactions with other neuromodulators showed an involvement of the serotonergic and noradrenergic systems, but not the glutamatergic or opioid systems, in the antidepressant-like effect of UA. Later work by the same team [152] revealed that ursolic acid exhibited some anxiolytic-like activities. Mice administered with UA performed open field test, elevated plus maze test, light/dark box test and marble burying test. The results show that ursolic acid $(10 \mathrm{mg} / \mathrm{kg})$ elicited an anxiolytic effect in the first and second test.

\subsection{Skeletal Muscles}

Skeletal muscles contraction powers the human body's movements and is essential for maintaining stability. Muscle tissue accounts for almost half of the human body mass and, in addition to its power-generating role, is a crucial factor in maintaining homeostasis. Given its central role in human mobility and metabolic function, any deterioration in the contractile, material, and metabolic properties of skeletal muscle has an extremely important effect on human health.

The term sarcopenia originates from the Greek words sarx (flesh) and penia (loss) and is used to describe the degenerative loss of muscle mass (atrophy) and its quality associated with aging. This expression is used to describe both: cellular processes (denervation, mitochondrial dysfunction, inflammatory and hormonal changes) and their outcomes such as decreased muscle strength, decreased mobility and function, increased fatigue and reduced energy needs. In addition, reduction of muscle mass in aged individuals has been associated with decreased survival rates following critical illnesses. It is estimated that sarcopenia affects more than $50 \%$ of people aged 80 and older [153].

To develop potential therapy against skeletal muscle atrophy Kunkel et al. [154] identified mRNA sequences regulated by fasting in human and mice muscles. These expression signatures were analyzed with Connectivity Map database and ursolic acid has been selected from over 1300 bioactive molecules as the one with the biggest anti-atrophic potential. Subsequent in vivo test on mice confirmed these capacities. Orally administered UA induced muscle hypertrophy, reduced denervation-induced muscle atrophy and changed the gene expression in muscles. Researchers 
connected triterpene activity with enhancing insulin/IGF-1 (insulin-like growth factor) signaling. A later paper by the same team [155] reports that UA increased Akt activity, as well as downstreamed mRNAs that promote glucose utilization (hexokinase-II), blood vessel recruitment (Vegfa) and autocrine/paracrine IGF-I signaling. As a result, skeletal muscle mass, fast and slow muscle fiber size, grip strength and exercise capacity were increased.

Bakhtiari et al. [156] were investigating if ursolic acid was able to rejuvenate skeletal muscles in vitro and in vivo. They found that UA elevated the expression of anti-aging genes SIRT1 (ca. 35 folds) and PGC-1a (ca. 175 folds). In vivo tests on a mice model revealed a decreased level of cellular energy charges (such as ATP and ADP) and increased proliferation and neomyogenesis in muscle cells. The authors draw the conclusion that UA can be considered as a potential candidate for the treatment of pathological conditions associated with muscular atrophy and dysfunction, such as skeletal muscle atrophy, amyotrophic lateral sclerosis (ALS) and sarcopenia.

The direct impact of UA on muscle strength was surveyed by a Korean team led by Bang [157]. Sixteen healthy male participants were divided into two groups (UA/placebo) and were performing resistance training for 8 weeks. Their characteristics, blood parameters and muscle strength were measured pre- and post-experiment. A significant increase in all muscle strength parameters was observed in the UA group, as well as a decrease of body fat and growth of IGF-1 and irisin in blood. The parameters of the placebo group remained unchanged.

\subsection{Bones}

Bone is a dynamic tissue that undergoes continual adaptation during life to attain and preserve skeletal size, shape and structural integrity. It consists of highly specialized cells, mineralized and unmineralized connective tissue matrix, and spaces that include the bone marrow cavity, vascular canals, canaliculi, and lacunae. When the skeleton reaches maturity, its development continues in the form of a periodic replacement of old bone with new at the same location. This process is called remodeling and is responsible for the complete regeneration of the adult skeleton every 10 years. The purpose of remodeling in the adult skeleton is not entirely clear, although in bones that are load bearing, this process most likely serves to repair fatigue damage and to prevent excessive aging and its consequences. Several types of cells are involved in the remodeling process, but the two most important are osteoblasts (bone-forming cells) and osteoclasts (cells able to remove mineralized bone matrix) [158].

The activity of osteoblasts and osteoclasts is crucial for maintaining proper bone structure and is regulated by differentiation from mesenchymal precursor cells and apoptosis. Several factors (e.g., sex steroid deficiency, senescence and glucocorticoid excess) can cause an imbalance between excessive osteoclastogenesis and inadequate osteoblastogenesis. The result is bone loss leading to osteopenia and osteoporosis [159]. Pharmacological treatment includes two categories: anti-resorptive agents (e.g., calcitonin or hormone replacement therapy) and anabolic agents (e.g., parathyroid analogues) [160].

Lee et al. [160] were the first to study the impact of ursolic acid on bone formation. They found that UA induces the expression of osteoblast-specific genes with the activation of mitogen-activated protein kinases, nuclear factor NF- $\mathrm{B}$ and activator protein-1. Another important outcome of their research was proving ursolic acids' bone-forming activity in vivo, in a mouse calvarial bone.

Tan et al. [161] found that triterpenic fraction from loquat (Eriobotrya japonica) was able to significantly decrease bone mineral density in oviarectomized mice by inhibiting osteoclast production. Dose-depended inhibitory effect of the extract on the differentiation of osteoclasts without any cytotoxicity was observed. A later paper by this research team [162] presents the results of an investigation of the structure-activity relationship of loquat extracts. It shows that, amongst 18 triterpenoids, ursolic and pomolic acid showed particularly strong inhibitory activity.

The possible mechanism of osteoclastogenesis inhibition by UA was evaluated by Jiang et al. [163]. The results indicated that UA can effectively suppress mRNA and protein expression 
by inhibiting NF- $\kappa B$ signaling and partially c-Jun N-terminal kinase signaling. Likewise, UA induced dose dependent attenuation of titanium particle-induced mouse calvarial bone loss. In conclusion, these results demonstrate that UA protects against wear particle-induced osteolysis by suppressing osteoclast formation and function.

$\mathrm{Yu}$ et al. [164] were investigating the impact of UA on the bone deleterious effect in streptozotocin-induced diabetic mice. Their results confirmed earlier observations: the enhancement of osteogenesis and the suppression on osteoclast differentiation. Research conducted by Fu et al. [165] was also carried out on diabetic-induced mice, however in this instance the aim was inhibiting tryptophan hydroxylase 1 (TPH1), one of the enzymes responsible for bone loss. Researchers synthesized several UA derivatives and investigated their inhibitive properties, obtaining molecules with improved features.

\subsection{Other Organs}

So far the influence of ursolic acid on other organs has been described only in a limited number of papers. The impact on skin has been investigated by two teams. One led by Both [166] has been testing liposome-encapsulated UA activity towards restoring and maintaining ceramide and collagen content in skin. Results showed that UA has been able to increase both the ceramide content of cultured normal human epidermal keratinocytes and the collagen content of cultured normal human dermal fibroblasts. In addition, UA liposomes increased the ceramide content of the skin of human subjects, with the increase occurring after only 3 days of treatment. On the other hand results of a study by Wójciak-Kosior et al. [167] present UA as a potent endangerment to skin. Ursolic and oleanolic acid activity against human skin fibroblasts (HSF) has been compared, showing that UA had exhibited much higher cytotoxic activity towards HSFs and thus it should not be used in dermal products.

Ding et al. [168] and Pai et al. [169] conducted research on the nephroprotective activity of UA. The teams were using aristolochic acid intoxicated zebrafish and gentamycin administrated rats, respectively. Both studies confirmed UA's ability to decrease chemically-induced damage to kidneys.

The protective effect of ursolic acid has been also tested by Chen et al. [170] in lipopolysaccharide-induced acute lung injury in a mouse model. UA markedly reduced lethality, improved survival time and decreased lung pathological changes. The results suggested that UA is capable of improving survival times in LPS-induced acute lung injury.

\section{Anti-Microbial Properties of Ursolic Acid}

\subsection{Anti-Bacterial Activity}

The fight against bacterial infections is one of the most important tasks of medicine. The development of antibiotics in the 1940s gave physicians a powerful tool against infections and has saved the lives of millions of people. However, because of the widespread and sometimes inappropriate use of these substances, strains of antibiotic-resistant bacteria have begun to emerge. These newer, stronger bacteria pose a significant threat to human health and a challenge to drug researchers. Therefore, there is a continuous search for new, safe antimicrobial agents, including those from natural sources. A number of researches has been performed to evaluate the anti-bacterial properties of ursolic acid and related compounds (Table 3). Some of them concerned in vitro determination of minimal inhibition concentration (MIC) of UA and other triterpenes against different strains of bacteria [171-174]. Others, like the work of Kurek et al. [175] focused on the specific effects of UA on bacterial metabolism (in this case the impact on peptidoglycan metabolism). 
Table 3. Anti-microbial and anti-parasitic activity of ursolic acid.

\begin{tabular}{|c|c|}
\hline Species & References \\
\hline \multicolumn{2}{|c|}{ Bacteria } \\
\hline Aeromonas caveae & [171] \\
\hline Bacillus cereus & {$[171,172]$} \\
\hline Bacillus sphaericus & [173] \\
\hline Bacillus subtilis & {$[173,176]$} \\
\hline Enterococcus faecalis & [177] \\
\hline Escherichia coli & {$[171,176,177]$} \\
\hline Klebisiella pneumoniae & [171] \\
\hline Listeria monocytogenes & {$[171,175,178]$} \\
\hline Mycobacterium tuberculosis & {$[179-181]$} \\
\hline Pseudomonas aeruginosa & {$[171,177]$} \\
\hline Pseudomonas syrinagae & [173] \\
\hline Ralstonia solanacearum & [175] \\
\hline Shigella flexneri & [171] \\
\hline Staphylococcus aureus & {$[171,176,177,182-184]$} \\
\hline Staphylococcus epidermis & [175] \\
\hline Streptococcus mutans & [185-187] \\
\hline Streptococcus pneumoniae & {$[178,183]$} \\
\hline Streptococcus sobrinus & [186] \\
\hline Streptomyces scabies & [176] \\
\hline Vibrio cholerae & [171] \\
\hline \multicolumn{2}{|c|}{ Viruses } \\
\hline Human immunodefiency virus & [188-192] \\
\hline Hepatitis $C$ virus & {$[189,193,194]$} \\
\hline Herpes simplex virus & [195] \\
\hline \multicolumn{2}{|c|}{ Protozoa } \\
\hline Leishmania amazonensis & [196] \\
\hline Plasmodium falciparum & [197-200] \\
\hline Trypanosoma brucei rhodesiense & [197] \\
\hline Trypanosoma cruzi & [201] \\
\hline \multicolumn{2}{|l|}{ Fungi } \\
\hline 11 species & [202] \\
\hline \multicolumn{2}{|c|}{ Nematodes (Roundworms) } \\
\hline Brugia malayi & [203] \\
\hline Wuchereria bancrofti & [203] \\
\hline
\end{tabular}

Ursolic acid activity against tuberculosis-causing Mycobacterium tuberculosis has been investigated by Woldemichael et al. [179] and Jiménez et al. [180]. They proved the activity of triterpenes (including UA) extracted from plants of known pharmaceutical activity-Calceolaria pinnifolia and Chamaedora tepejilote. Further research by Jiménez-Arellanes et al. [181] confirmed that UA can be used against drug-resistant strains of these bacteria.

The ability to overcome bacterial resistance against antibiotics was also tested by Horiuchi et al. [182] who focused their work on vancomycin-resistant Enterococci and Kim et al. [183] who used methicillin-resistant Staphylococcus aureus. Both studies showed that UA can be used simultaneously with antibiotics to enhance their activity.

$\mathrm{Hu}$ et al. [174] conducted research on sepsis induced by cecal ligation and puncture. They found that injections of UA were able to significantly improve survival and attenuate lung injury of infected rats.

The impact of orally delivered ursolic acid on intestinal microbiota was studied by Feng et al. [204]. Their results showed that it decreased the microbial diversity in the proximal intestine while having an opposite effect in the distal intestine. UA also inhibited colonization by energy harvest-related microbes and might be able to enhance intestinal health by inhibiting colonization by Proteobacteria. 


\subsection{Anti-Viral Properties}

The human immunodeficiency virus (HIV) and human hepatitis C virus (HCV) infections are chronic and wide-spread illnesses that represent serious public health problems. According to a 2012 UNAIDS report on the global AIDS epidemic, about 34 million people were living with HIV, 2.5 million had acquired new HIV infections and 1.7 million had died of HIV-related causes worldwide during 2011.

HIV-1 protease is a retroviral aspartyl protease that is essential for the life-cycle of HIV. It cleaves newly synthesized polyproteins at the appropriate places to create the mature protein components of an infectious HIV virion. Due to its importance in metabolism this enzyme became the prime target for drug therapy. In 1996 Quere et al. [192] found that ursolic acid can act as an inhibitor of this protease, with $\mathrm{IC}_{50}$ near $1 \mu \mathrm{M}$. The expected mechanism of action was dimerization inhibition. Kashiwada et al. [190] confirmed these results and compared the activity of various triterpenes. Subsequent works focused mainly on inhibiting HIV-1 protease using plant extracts rather than pure compounds, due to its lower price and easier access [188,189,191].

It is also estimated that about $3 \%$ of the global population is infected with the hepatitis $\mathrm{C}$ virus. Chronic hepatitis $\mathrm{C}$ infection is the leading cause of cirrhosis, hepatocellular carcinoma and liver transplantations in developed countries [189]. Anti-HCV properties of UA were discovered recently. Kong et al. [193] reported that triterpenes are responsible for the anti-viral activity of the Chinese herb Ligustrum lucidum. Virus spreading was inhibited, at least partly, by suppressing NS5B RNA-dependent RNA polymerase. Garcia-Risco et al. [194] investigated extracts of heather (Calluna vulgaris) and they confirmed UA activity against human hepatitis virus C.

Research conducted by Bag et al. [195] showed that UA is an active agent responsible for the anti-herpes activity of Mallotus peltatus extract. Investigators claimed that UA was probably inhibiting the early stage of multiplication and can be used as an anti-HSV agent.

\subsection{Activity against other Microbes and Parasites}

Malaria is the parasitic disease with the greatest impact-it affects around $40 \%$ of the world's population, spanning across more than 100 countries. Its etiological agent is a protozoa belonging to the genus Plasmodium.

In 2006 two independent research teams led by van Baren [197] and Cimanga [200] discovered that triterpenes (including UA) were responsible for the anti-malarial activity of extracts from Satureja parvifolia and Morinda lucida. Innocente et al. [198] and Della-Veccia et al. [199] developed UA derivatives and evaluated them by their anti-Plasmodium activity. Despite using different modification methods both teams acquired compounds with very high anti-malarial properties.

Yamamoto et al. [196] investigated the impact of UA on mice infected with Leishmania amazonensis. The curative effect of triterpene-rich fraction was similar to amphotericin B (often used in clinical therapy), however the dose required to eliminate microbes was smaller. Moreover, triterpenic fraction did not cause microscopic alterations in the liver, spleen, heart, lung, and kidney of the experimental groups.

The influence of UA on the treatment of Trypanosoma cruzi infections was reported by de Silva Pereirra et al. [201] They found that oral administration of UA can significantly reduce the parasitic peak during the acute phase of infection.

Ursolic acid, betulinic acid and six of their derivatives were tested against eleven mucocutaneous and cutaneous mycotic agents [202]. The MIC values of the piperazinyl derivatives against pathogenic yeast were in the range of $16-32 \mu \mathrm{g} / \mathrm{mL}$.

The activity of UA was also examined against parasites. Saini et al. [203] evaluated the activity of UA extracted from Nycanthes arbor-tristis against Brugia malayi and Wuchereria bancrofti-tropical filariae responsible for elephantiasis. They discovered that UA was able to induce apoptosis of these nematodes by downregulating and altering the level of some key antioxidants. 


\section{Conclusions}

Ursolic acid is a widespread compound of plant origin exhibiting wide range of the pharmacological activities. The biggest attention amongst scientists has been captured by the role that UA can play in treatment and prevention of cancer. Amongst other intriguing features of this triterpene anti-microbial properties and protective effect on internal organs against chemical-damage should be mentioned. However some studies point out negative effects of administration of this compound, suggesting that impact of UA on human's health in some cases can be compared to the double-edged sword. Analysis of literature indicates that various effects can be linked to one phenomenon. The example might be inhibition of NF-KB activity, which leads to cancer cells apoptosis, anti-inflammatory effects and bone-forming activity.

Conflicts of Interest: The authors declare no conflict of interest.

\section{References}

1. Laszczyk, M.N. Pentacyclic triterpenes of the lupane, oleanane and ursane group as tools in cancer therapy. Planta Med. 2009, 75, 1549-1560. [CrossRef] [PubMed]

2. Jesus, J.A.; Lago, J.H.G.; Laurenti, M.D.; Yamamoto, E.S.; Passero, L.F. Antimicrobial activity of oleanolic and ursolic acid: An update. Evid. Based Complement. Altern. Med. 2015, 2015. [CrossRef] [PubMed]

3. Shanmugam, M.K.; Dai, X.; Kumar, A.P.; Tan, B.K.H.; Sethi, G.; Bishayee, A. Ursolic acid in cancer prevention and treatment: Molecular targets, pharmacokinetics and clinical studies. Biochem. Pharmacol. 2013, 85, 1579-1587. [CrossRef] [PubMed]

4. Ovesná, Z.; Vachálková, A.; Horváthová, K.; Tóthová, D. Pentacyclic triterpenoic acids: New chemoprotective compounds. Minireview. Neoplasma 2004, 51, 327-333. [PubMed]

5. Dzubak, P.; Hajduch, M.; Vydra, D.; Hustova, A.; Kvasnica, M.; Biedermann, D.; Markova, L.; Urban, M.; Sarek, J. Pharmacological activities if natural triterpenoids and their therapeutic implications. Nat. Prod. Res. 2006, 23, 394-411. [CrossRef]

6. Liu, J. Oleanolic and ursolic acid: Research perspectives. J. Ethnopharmacol. 2005, 100, 92-94. [CrossRef] [PubMed]

7. Liu, J. Pharmacology of oleanolic and ursolic acid. J. Ethnopharmacol. 1995, 49, 57-68. [CrossRef]

8. Jäger, S.; Trojan, H.; Kopp, T.; Laszczyk, M.N.; Scheffler, A. Pentacyclic triterpene distribution in various plants-Rich sources for a new group of multi-potent plant extracts. Molecules 2009, 14, 2016-2031. [CrossRef] [PubMed]

9. Szakiel, A.; Paczkowski, C.; Pensec, F.; Bertsch, C. Fruit cuticular waxes as a source of biologically active triterpenoids. Phytochem. Rev. 2012, 11, 263-284. [CrossRef] [PubMed]

10. Świeżewska, E.; Danikiewicz, W. Polyisoprenoids: Structure, biosynthesis and function. Prog. Lip. Res. 2005, 44, 235-258. [CrossRef] [PubMed]

11. Hemmerlin, A.; Harwood, J.L.; Bach, T.J. A raison d'être for two distinct pathways in the early steps of plant isoprenoid biosynthesis? Prog. Lip. Res. 2012, 51, 95-148. [CrossRef] [PubMed]

12. Bouvier, F.; Rahier, A.; Camara, B. Biogenesis, molecular regulation and function of plant isoprenoids. Prog. Lip. Res. 2005, 44, 357-429. [CrossRef] [PubMed]

13. Thimmappa, R.; Geisler, K.; Louveau, T.; O'Maille, P.; Osbourn, A. Triterpene biosynthesis in plants. Annu. Rev. Plant Biol. 2015, 65, 225-257. [CrossRef] [PubMed]

14. Zheng, Q.Y.; Li, P.P.; Jin, F.S.; Yao, C.; Zhang, G.H.; Zang, T.; Ai, X. Ursolic acid induces ER stress response to activate ASK1-JNK signaling and induce apoptosis in human bladder cancer T24 cells. Cell Signal. 2013, 25, 206-213. [CrossRef] [PubMed]

15. Tu, H.Y.; Huang, A.M.; Wei, B.L.; Gan, K.H.; Hour, T.C.; Yang, S.C.; Pu, Y.S.; Lin, C.N. Ursolic acid derivatives induce cell cycle arrest and apoptosis in NTUB1 cells associated with reactive oxygen species. Bioorg. Med. Chem. 2009, 17, 7265-7274. [CrossRef] [PubMed]

16. De Angel, R.E.; Smith, S.M.; Glickman, R.D.; Perkins, S.N.; Hursting, S.D. Antitumor effects of ursolic acid in a mouse model of postmenopausal breast cancer. Nutr. Cancer 2010, 62, 1074-1086. [CrossRef] [PubMed] 
17. Shan, J.Z.; Xuan, Y.Y.; Ruan, S.Q.; Sun, M. Proliferation-inhibiting and apoptosis-inducing effects of ursolic acid and oleanolic acid on multi-drug resistance cancer cells in vitro. Chin. J. Integr. Med. 2011, 17, 607-611. [CrossRef] [PubMed]

18. He, X.; Liu, R.L. Triterpenoids isolated from apple peels have potent antiproliferative activity and may be partially responsible for apple's anticancer activity. J. Agric. Food Chem. 2007, 55, 4366-4370. [CrossRef] [PubMed]

19. Yeh, C.T.; Wu, C.H.; Yen, G.C. Ursolic acid, a naturally occurring triterpenoid, suppresses migration and invasion of human breast cancer cells by modulating C-Jun N-terminal kinase, Akt and mammalian target of rapamycin signaling. Mol. Nutr. Food Res. 2010, 54, 1285-1295. [CrossRef] [PubMed]

20. Kim, K.H.; Seo, H.S.; Choi, H.S.; Choi, I.; Shin, Y.C.; Ko, S.G. Induction of apoptotic cell death by ursolic acid through mitochondrial death pathway and extrinsic death receptor pathway in MDA-MB-231 cells. Arch. Pharm. Res. 2011, 34, 1363-1372. [CrossRef] [PubMed]

21. Wang, J.S.; Ren, T.N.; Xi, T. Ursolic acid induces apoptosis by suppressing the expression of in MCF-7 human breast cancer cells. Med. Oncol. 2012, 29, 10-15. [CrossRef] [PubMed]

22. Ma, C.M.; Cai, S.Q.; Cui, J.R.; Wang, R.Q.; Tu, P.F.; Hattori, M.; Daneshtalab, M. The cytotoxic activity of ursolic acid derivatives. Eur. J. Med. Chem. 2005, 40, 582-589. [CrossRef] [PubMed]

23. Mallavadhani, U.V.; Mahapatra, A.; Pattnaik, B.; Vanga, N.; Suri, N.; Saxena, A.K. Synthesis and anti-cancer activity of some novel C-17 analogs of ursolic and oleanolic acids. Med. Chem. Res. 2013, 22, 1263-1269. [CrossRef]

24. Shao, J.W.; Dai, Y.C.; Xue, J.P.; Wang, J.C.; Lin, F.P.; Guo, Y.H. In vitro and in vivo anticancer activity evaluation of ursolic acid derivatives. Eur. J. Med. Chem. 2011, 46, 2652-2661. [CrossRef] [PubMed]

25. Li, Y.; Lu, X.; Qi, H.; Li, X.; Xiao, X.; Gao, J. Ursolic acid induces apoptosis trough mitochondrial intrinsic pathway and suppression of ERK1/2 MAPK in HeLa cells. J. Pharmacol. Sci. 2014, 125, 202-210. [CrossRef] [PubMed]

26. Li, Y.; Xing, D.; Chen, Q.; Chen, W.R. Enhancement of chemotherapeutic agent-induced apoptosis by inhibition of NF-kB using ursolic acid. Int. J. Cancer 2010, 127, 462-473. [CrossRef] [PubMed]

27. Srivastava, P.; Kasoju, N.; Bora, U.; Chaturvedi, R. Accumulation of betulinic, oleanolic and ursolic acids in In vitro cell cultures of Lantana camara L. and their significant cytotoxic effects on HeLa cell lines. Biotechnol. Bioprocess Eng. 2010, 15, 1038-1046. [CrossRef]

28. Xavier, C.P.; Lima, C.F.; Preto, A.; Seruca, R.; Fernandes-Ferreira, M.; Pereira-Wilson, C. Luteolin, quercetin and ursolic acid are potent inhibitors of proliferation and inducers of apoptosis in both KRAS and BRAF mutated human colorectal cancer cells. Cancer Lett. 2009, 281, 162-170. [CrossRef] [PubMed]

29. Kim, J.H.; Kim, Y.H.; Song, G.Y.; Kim, D.E.; Jeong, Y.J.; Liu, K.H.; Chung, Y.H.; Oh, S. Ursolic acid and its natural derivative corosolic acid suppress the proliferation of APC-mutated colon cancer cells through promotion of $\beta$-catenin degradation. Food Chem. Toxicol. 2014, 67, 87-95. [CrossRef] [PubMed]

30. Prasad, S.; Yadav, V.; Sung, B.; Reuter, S.; Kannappan, R.; Deorukhkar, A.; Diagaradjane, P.; Wei, C.; Baladandayuthapani, V.; Krishnan, S.; et al. Ursolic acid inhibits growth and metastasis of human colorectal cancer in an orthotopic nude mouse model by targeting multiple cell signaling pathways: Chemosensitization with capecitabine. Clin. Cancer Res. 2012, 18, 4942-4953. [CrossRef] [PubMed]

31. Prasad, S.; Yadav, V.R.; Kannappan, R.; Aggarwal, B.B. Ursolic acid, a pentacyclic triterpene, potentiates TRAIL-induced apoptosis through p53-independent upregulation of death receptors: Evidence for the role of reactive oxygen species and JNK. J. Biol. Chem. 2011, 286, 5546-5557. [CrossRef] [PubMed]

32. Nam, H.; Kim, M.M. Ursolic acid induces apoptosis of SW480 cells via p53 activation. Food Chem. Toxicol. 2013, 62, 579-583. [CrossRef] [PubMed]

33. Xavier, C.P.; Lima, C.F.; Pedro, D.F.; Wilson, J.M.; Kristiansen, K.; Pereira-Wilson, C. Ursolic acid induces cell death and modulates autophagy through JNK pathway in apoptosis-resistant colorectal cancer cells. J. Nutr. Biochem. 2013, 24, 706-712. [CrossRef] [PubMed]

34. Limami, Y.; Pinon, A.; Leger, D.Y.; Pinault, E.; Delage, C.; Beneytout, J.L.; Simon, A.; Liarge, B. The $\mathrm{P} 2 \mathrm{Y} 2 / \mathrm{Src} / \mathrm{p} 38 / \mathrm{COX}-2$ pathway is involved in the resistance to ursolic acid-induced apoptosis in colorectal and prostate cancer cells. Biochimie 2012, 94, 1754-1763. [CrossRef] [PubMed]

35. Koh, S.J.; Tak, J.K.; Kim, S.T.; Nam, W.S.; Kim, S.Y.; Park, K.M.; Park, J.W. Sensitization of ionizing radiation-induced apoptosis by ursolic acid. Free Radic. Res. 2012, 46, 339-345. [CrossRef] [PubMed] 
36. Bai, K.K.; Yu, Z.; Chen, F.L.; Li, F.; Li, W.Y.; Guo, Y.H. Synthesis and evaluation of ursolic acid derivatives as potent cytotoxic agents. Bioorg. Med. Chem. Lett. 2012, 7, 2488-2493. [CrossRef] [PubMed]

37. Cha, H.J.; Bae, S.K.; Lee, H.Y.; Lee, O.H.; Sato, H.; Seiki, M.; Park, B.C.; Kim, K.W. Anti-invasive activity of ursolic acid correlates with the reduced expression of matrix metalloproteinase-9 (MMP-9) in HT1080 human fibrosarcoma cells. Cancer Res. 1996, 56, 2281-2284. [PubMed]

38. Kim, E.S.; Moon, A. Ursolic acid inhibits the invasive phenotype of SNU-484 human gastric cancer cells. Oncol. Lett. 2015, 9, 897-902. [CrossRef] [PubMed]

39. Wang, X.; Zhang, F.; Yang, L.; Mei, Y.; Long, H.; Zhang, X.; Zhang, J.; Qimuge-Suyila; Su, X. Ursolic acid inhibits proliferation and induces apoptosis of cancer cells in vitro and in vivo. J. Biomed. Biotechnol. 2011, 2011. [CrossRef] [PubMed]

40. Zhang, H.; Li, X.; Ding, J.; Xu, H.; Dai, X.; Hou, Z.; Zhang, K.; Sun, K.; Sun, W. Delivery of ursolic acid (UA) in polymeric nanoparticles effectively promotes the apoptosis of gastric cancer cells through enhanced inhibition of cyclooxygenase 2 (COX-2). Int. J. Pharm. 2013, 441, 261-268. [CrossRef] [PubMed]

41. Huang, H.C.; Huang, C.Y.; Lin-Shiau, S.Y.; Lin, J.K. Ursolic acid inhibits IL-2 beta or TF-alpha-induced C6 glioma invasion through suppressing the association ZIP/p62 with PKC-zeta and downregulating the MMP-9 expression. Mol. Carcinog. 2009, 48, 517-531. [CrossRef] [PubMed]

42. Wang, J.; Li, Y.; Wang, X.; Jiang, C. Ursolic acid inhibits proliferation and induces apoptosis in human glioblastoma cell lines U251 by suppressing TGF $\beta-1 / \mathrm{miR}-21 / \mathrm{PDCD} 4$ pathway. Basic Clin. Pharmacol. Toxicol. 2012, 111, 106-112. [PubMed]

43. Bonaccorsi, I.; Altieri, F.; Sciamanna, I.; Oricchio, E.; Grillo, C.; Contartese, G.; Galati, E.M. Endogenous reverse transcriptase as a mediator of ursolic acid's anti-proliferative and differentiating effects in human cancer cell lines. Cancer Lett. 2008, 263, 130-139. [CrossRef] [PubMed]

44. Martin, R.; Carvalho, J.; Ibeas, E.; Hernández, M.; Ruiz-Guttierez, V.; Nieto, M.L. Acidic triterpenes compromise growth and survival of astrocytoma cell lines by regulating reactive oxygen species accumulation. Cancer Res. 2007, 67, 3741-3751. [CrossRef] [PubMed]

45. Shih, W.L.; Yu, F.L.; Chang, C.D.; Liao, M.H.; Wu, H.Y.; Lin, P.Y. Suppression of AMF/PGI-mediated tumorigenic activities by ursolic acid in cultured hepatoma cells and in a mouse model. Mol. Carcinog. 2013, 52, 800-812. [CrossRef] [PubMed]

46. Tian, Z.; Lin, G.; Zheng, R.X.; Huang, F.; Yang, M.S.; Xiao, P.G. Anti-hepatoma activity and mechanism of ursolic acid and its derivatives isolated from Aralia decaisneana. World J. Gastroenterol. 2006, 12, 874-879. [PubMed]

47. Liu, L.; Zhang, J.; Li, M.; Zhang, X.; Zhang, J.; Li, Z.; Wang, L.; Wu, J.; Luo, C. Inhibition of HepG2 cell proliferation by ursolic acid and polysaccharides via the downregulation of cyclooxygenase- 2 . Mol. Med. Rep. 2014, 9, 2505-2511. [CrossRef] [PubMed]

48. Shyu, M.H.; Kao, T.C.; Yen, G.C. Oleanolic acid and ursolic acid induce apoptosis in HuH7 human hepatocellular carcinoma cells through a mitochondrial-dependent pathway and downregulation of XIAP. J. Agric. Food Chem. 2010, 58, 6110-6118. [CrossRef] [PubMed]

49. Tang, C.; Lu, Y.H.; Xie, J.H.; Wang, F.; Zou, J.N.; Yang, J.S.; Xing, Y.Y.; Xi, T. Downregulation of survivin and activation of caspase-3 through the PI3K/Akt pathway in ursolic acid-induced HepG2 cell apoptosis. Anti-Cancer Drugs 2009, 20, 249-258. [CrossRef] [PubMed]

50. Lin, C.C.; Huang, C.Y.; Mong, M.C.; Chan, C.Y.; Yin, M.C. Antiangiogenic potential of three triterpenic acids in human liver cancer cells. J. Agric. Food Chem. 2011, 59, 755-762. [CrossRef] [PubMed]

51. Kanjoormana, M.; Kuttan, G. Antiangiogenic activity of ursolic acid. Integr. Cancer Ther. 2010, 9, $224-235$. [CrossRef] [PubMed]

52. Harmand, P.O.; Duval, R.; Delage, C.; Simon, A. Ursolic acid induces apoptosis through mitochondrial intrinsic pathway and caspase-3 activation in M4Beu melanoma cells. J. Cancer 2005, 114, 1-11. [CrossRef] [PubMed]

53. Duval, R.E.; Harmand, P.O.; Jayat-Vignoles, C.; Cook-Moreau, J.; Pinon, A.; Delage, C.; Simon, A. Differential involvement of mitochondria during ursolic acid-induced apoptotic process in HaCaT and M4Beu cells. Oncol. Rep. 2008, 19, 145-149. [CrossRef] [PubMed]

54. Manu, K.A.; Kutan, G. Ursolic acid induces apoptosis by activating p53 and caspase-3 gene expressions and suppressing NF-kappaB mediated activation of bcl-2 in B16F-10 melanoma cells. Int. Immunopharmacol. 2008, 8, 974-981. [CrossRef] [PubMed] 
55. Li, G.; Zhou, T.; Liu, L.; Chen, J.; Zhao, Z.; Peng, Y.; Li, P.; Gao, N. Ezrin dephosphorylation/downregulation contributes to ursolic acid-mediated cell death in human leukemia cells. Blood Cancer J. 2013, 3, e108. [CrossRef] [PubMed]

56. Wu, B.; Wang, X.; Chi, Z.F.; Hu, R.; Zhang, R.; Yang, W.; Liu, Z.G. Ursolic acid-induced apoptosis in K562 cells involving upregulation of PTEN gene expression and inactivation of the PI3K/Akt pathway. Arch. Pharm. Res. 2012, 35, 543-548. [CrossRef] [PubMed]

57. Gao, N.; Cheng, S.; Budhjara, A.; Gao, Z.; Chen, J.; Liu, E.H.; Huang, C.; Chen, D.; Yang, Z.; Liu, Q.; et al. Ursolic acid induces apoptosis in human leukaemia cells and inhibits anti-leukaemic activity in nude mice through the PKB pathway. Br. J. Pharmacol. 2012, 165, 1813-1826. [CrossRef] [PubMed]

58. Baek, J.H.; Lee, Y.S.; Kang, C.M.; Kim, J.A.; Kwon, K.S.; Son, H.C.; Kim, K.W. Intracellular Ca ${ }^{2+}$ release mediates ursolic acid-induced apoptosis in human leukemic HL-60 cells. Int. J. Cancer 1997, 73, 725-728. [CrossRef]

59. Zhang, T.; He, Y.M.; Wang, J.S.; Shen, J.; Xing, Y.Y.; Xi, T. Ursolic acid induces HL60 monocytic differentiation and upregulates C/EBP $\beta$ expression by ERK pathway activation. Anticancer Drugs 2011, 22, 158-165. [CrossRef] [PubMed]

60. Huang, C.Y.; Lin, C.Y.; Tsai, C.W.; Yin, M.C. Inhibition of cell proliferation, invasion and migration by ursolic acid in human lung cancer cell lines. Toxicol. Vitro 2011, 25, 1274-1280. [CrossRef] [PubMed]

61. Liu, K.; Guo, L.; Miao, L.; Bao, W.; Yang, J.; Li, X.; Xi, T.; Zhao, W. Ursolic acid inhibits epithelial-mesenchymal transition by suppressing the expression of astrocyte-elevated gene- 1 in human nonsmall cell lung cancer A549 cells. Anticancer Drugs 2013, 24, 494-503. [CrossRef] [PubMed]

62. Lai, M.Y.; Leung, H.W.C.; Yang, W.H.; Chen, W.H.; Lee, H.Z. Upregulation of matrix metalloproteinase family gene involvement in ursolic acid induced human lung non-small carcinoma cell apoptosis. Anticancer Res. 2007, 27, 145-153. [PubMed]

63. Lauthier, F.; Taillet, L.; Trouillas, P.; Delage, C.; Simon, A. Ursolic acid triggers calcium-dependent apoptosis in human Daudi cells. Anticancer Drugs 2000, 11, 737-745. [CrossRef] [PubMed]

64. Pathak, A.K.; Bhutani, M.; Nair, A.S.; Ahn, K.S.; Chakraborty, A.; Kadara, H.; Guha, S.; Sethi, G.; Aggarwal, B.B. Ursolic acid inhibits STAT3 activation pathway leading to suppression of proliferation and chemosensitization of human myeloma cells. Mol. Cancer Res. 2007, 5, 943-955. [CrossRef] [PubMed]

65. Wang, X.; Li, L.; Wang, B.; Xiang, J. Effects of ursolic acid on the proliferation and apoptosis of human ovarian cancer cells. J. Huazhong Univ. Sci. Technol. Med. Sci. 2009, 29, 761-764. [CrossRef] [PubMed]

66. Song, Y.H.; Jeong, S.J.; Kwon, H.Y.; Kim, B.; Sim, S.H.; Yoo, D.Y. Ursolic acid from Oldenlandia diffusa induces apoptosis via activation of caspases and phosphorylation of glycogen synthase kinase 3 beta in SK-OV-3 ovarian cancer cells. Biol. Pharm. Bull. 2012, 35, 1022-1028. [CrossRef] [PubMed]

67. Leal, A.S.; Wang, R.; Salvador, J.A.; Jing, Y. Synthesis of novel ursolic acid heterocyclic derivatives with improved abilities of antiproliferation and induction of p53, p21 waf1 and NOXA in pancreatic cancer cells. Bioorg. Med. Chem. 2012, 20, 5774-5786. [CrossRef] [PubMed]

68. Li, J.; Liang, X.; Yang, X. Ursolic acid inhibits growth and induces apoptosis in gemcitabine-resistant human pancreatic cancer via the JNK and PI3K/Akt/NF-kB pathways. Oncol. Rep. 2012, 28, 501-510. [PubMed]

69. Shanmugam, M.K.; Manu, K.A.; Ong, T.H.; Ramachandran, L.; Surana, R.; Bist, P.; Lim, L.H.K.; Kumar, A.P.; Hui, K.M.; Sethi, G. Inhibition of CXCR4/CXCL12 signaling axis by ursolic acid leads to suppression of metastasis in transgenic adenocarcinoma of mouse prostate model. Int. J. Cancer 2011, 129, 1552-1563. [CrossRef] [PubMed]

70. Shanmugam, M.K.; Ong, T.H.; Kumar, A.P.; Lun, C.K.; Ho, P.C.; Wong, P.T.; Hui, K.M.; Sethi, G. Ursolic acid inhibits the initiation, progression of prostate cancer and prolongs the survival of TRAMP mice by modulating pro-inflammatory pathways. PLoS ONE 2012, 7, e32476. [CrossRef] [PubMed]

71. Choi, Y.H.; Baek, J.H.; Yoo, M.A.; Chung, H.Y.; Kim, N.D.; Kim, K.W. Induction of apoptosis by ursolic acid through activation of caspases and down-regulation of c-IAPs in human prostate epithelial cells. Int. J. Oncol. 2000, 17, 565-636. [CrossRef] [PubMed]

72. Shin, S.W.; Kim, S.Y.; Park, J.W. Autophagy inhibition enhances ursolic acid-induced apoptosis in PC3 cells. Biochim. Biophys. Acta 2012, 1823, 451-457. [CrossRef] [PubMed]

73. Zhang, Y.; Kong, C.; Zeng, Y.; Wang, L.; Li, Z.; Wang, H.; Xu, C.; Sun, Y. Ursolic acid induces PC-3 cell apoptosis via activation of JNK and inhibition of Akt pathways in vitro. Mol. Carcinogen. 2010, 49, 374-385. [CrossRef] [PubMed] 
74. Zhang, Y.; Kong, C.; Wang, L.; Li, J.; Liu, X.; Xu, B.; Xu, C.; Sun, Y. Ursolic acid overcomes Bcl-2-mediated resistance to apoptosis in prostate cancer cells involving activation of JNK-induced Bcl-2 phosphorylation and degradation. J. Cell Biochem. 2010, 109, 764-773. [CrossRef] [PubMed]

75. Kassi, E.; Papoutsi, Z.; Pratsinis, H.; Aligiannis, N.; Manoussakis, M.; Moutsatsou, P. Ursolic acid, a naturally occurring triterpenoid, demonstrates anticancer activity on human prostate cancer cells. J. Cancer Res. Clin. Oncol. 2007, 133, 493-500. [CrossRef] [PubMed]

76. Ku, C.M.; Lin, J.Y. Anti-inflammatory effect of 27 selected terpenoid compounds tested through modulating Th1/Th2 cytokine secretion profiles using murine primary splenocytes. Food Chem. 2013, 141, 1104-1113. [CrossRef] [PubMed]

77. Checker, R.; Sandur, S.K.; Sharma, D.; Patwardhan, R.S.; Jayakumar, S.; Kohli, V.; Sethi, G.; Aggarwal, B.B.; Sainis, K.B. Potent anti-inflammatory activity of ursolic acid, a triterpenoid antioxidant, is mediated through suppression of NF-kB, AP-1 and NF-AT. PLoS ONE 2012, 7, e31318. [CrossRef] [PubMed]

78. Recio, M.C.; Giner, R.M.; Máñez, S.; Gueho, J.; Julien, H.R.; Hostettmann, K.; Rios, J.L. Investigations on the steroidal anti-inflammatory activity of triterpenoids from Diospyros leucomelas. Planta Med. 1995, 61, 9-12. [CrossRef] [PubMed]

79. Kim, S.H.; Hong, J.H.; Lee, J.C. Ursolic acid, a potential PPAR $\gamma$ agonist, suppresses ovalbumin-induced airway inflammation and Penh by down-regulating IL-5, IL-13 and IL-17 in a mouse model of allergic asthma. Eur. J. Pharmacol. 2013, 701, 131-143. [CrossRef] [PubMed]

80. Chun, J.; Lee, C.; Hwang, S.W.; Im, J.P.; Kim, J.S. Ursolic acid inhibits nuclear factor- $\mathrm{kB}$ signaling in intestinal epithelial cells and macrophages, and attenuates experimental colitis in mice. Life Sci. 2014, 110, $23-34$. [CrossRef] [PubMed]

81. Tsuruga, T.; Chun, Y.T.; Ebizuka, Y.; Sankawa, U. Biologically active constituents of Melaleuca leucadendron: Inhibitors of induced histamine release from rat mast cells. Chem. Pharm. Bull. 1991, 39, 3276-3278. [CrossRef] [PubMed]

82. Cha, D.S.; Eun, J.S.; Jeon, H. Anti-inflammatory and antinociceptive properties of the leaves of Eriobotrya japonica. J. Ethnopharmacol. 2011, 134, 305-312. [CrossRef] [PubMed]

83. Tsai, S.J.; Yin, M.C. Antioxidative and anti-inflammatory protection of oleanolic acid and ursolic acid in PC12 cells. J. Food Sci. 2008, 73, H174-H178. [CrossRef] [PubMed]

84. Baricevic, D.; Sosa, S.; Della Loggia, R.; Tubaro, A.; Simonovska, B.; Krasna, A.; Zupancic, A. Topical anti-inflammatory activity of Salvia officinalis L. leaves: The relevance of ursolic acid. J. Ethnopharmacol. 2001, 75, 125-132. [CrossRef]

85. Benincá, J.P.; Dalmarco, J.B.; Pizzolatti, M.G.; Fröde, T.S. Analysis of the anti-inflammatory properties of Rosmarinus officinalis L. in mice. Food Chem. 2011, 124, 468-475. [CrossRef]

86. Santos Rosa, C.; Garcia Gimenez, M.D.; Saenz Rodriguez, M.T.; de la Puerta Vazquez, R. Antihistaminic and antieicosanoid effects of oleanolic and ursolic acid fraction from Helichrysum picardii. Int. J. Pharm. Sci. 2007, 62, 459-462.

87. Ahmad, S.F.; Khan, B.; Bani, S.; Suri, K.A.; Satti, N.K.; Qazi, G.N. Amelioration of adjuvant-induced arthritis by ursolic acid through altered Th1/Th2 cytokine production. Pharmacol. Res. 2006, 53, 233-240. [CrossRef] [PubMed]

88. Xu, T.; Wang, X.; Zhong, B.; Nurieva, R.I.; Ding, S.; Dong, C. Ursolic acid suppresses interleukin-17 (Il-17) production by selectively antagonizing the function of ROR $\gamma$ t protein. J. Biol. Chem. 2011, 286, 22707-22710. [CrossRef] [PubMed]

89. Ringbom, T.; Segura, L.; Noreen, Y.; Perera, P.; Bohlin, L. Ursolic acid from Plantago major, a selective inhibitor of cyclooxygenase-2 catalyzed prostaglandin biosynthesis. J. Nat. Prod. 1998, 61, 1212-1215. [CrossRef] [PubMed]

90. Balanehru, S.; Nagarajan, B. Protective effect of oleanolic and ursolic acid against lipid peroxidation. Biochem. Int. 1991, 24, 981-990. [PubMed]

91. Kwon, T.H.; Lee, B.; Chung, S.H.; Kim, D.H.; Lee, Y.S. Synthesis and NO production inhibitory activities of ursolic acid and oleanolic acid derivatives. Bull. Korean Chem. Soc. 2009, 30, 119-123. [CrossRef]

92. Liobikas, J.; Majiene, D.; Trumbeckaite, S.; Kursvietiene, L.; Masteikova, R.; Kopustinskien, D.M.; Savickas, A.; Bernatoniene, J. Uncoupling and antioxidant effect of ursolic acid in isolated rat heart mitochondria. J. Nat. Prod. 2011, 74, 1640-1644. [CrossRef] [PubMed] 
93. Ramachandran, S.; Rajendra Prasad, N.; Pugalendi, K.V.; Menon, V.P. Modulation of UVB-induced oxidative stress by ursolic acid in human blood lymphocytes. Asian J. Biochem. 2008, 3, 11-18.

94. Ramos, A.A.; Pereira-Wilson, C.; Collins, A.R. Protective effects of ursolic acid and luteolin against oxidative DNA damage include enhancement of DNA repair in Caco-2 cells. Mutat. Res. 2010, 692, 6-11. [CrossRef] [PubMed]

95. Huang, M.T.; Ho, C.T.; Wang, Z.Y.; Ferraro, T.; Lou, Y.R.; Stauber, K.; Ma, W.; Georgiadis, C.; Laskin, J.D.; Conney, A.H. Inhibition of skin tumorigenesis by rosemary and its constituents carnosol and ursolic acid. Cancer Res. 1994, 54, 701-708. [PubMed]

96. Furtado, R.A.; Rodrigues, É.P.; Araújo, F.R.R.; Oliveira, W.L.; Furtado, M.A.; Castro, M.B.; Cunha, W.R.; Tavares, D.C. Ursolic acid and oleanolic acid suppress preneoplastic lesions induced by 1,2-dimethylhydrazine in rat colon. Toxicol. Pathol. 2008, 36, 576-580. [CrossRef] [PubMed]

97. Andersson, D.; Cheng, Y.; Duan, R.D. Ursolic acid inhibits the formation of aberrant crypt foci and affects colonic sphingomyelin hydrolyzing enzymes in azoxymethane-treated rats. J. Cancer Res. Clin. Oncol. 2008, 134, 101-107. [CrossRef] [PubMed]

98. Liu, W.; Tan, X.; Shu, L.; Song, J.; Jin, P.; Yu, S.; Sun, M.; Jia, X. Ursolic acid inhibits cigarette smoke extract-induced human bronchial epithelial cell injury and prevents development of lung cancer. Molecules 2012, 17, 9104-9115. [CrossRef] [PubMed]

99. Hsu, H.Y.; Yang, J.J.; Lin, C.C. Effects of oleanolic and ursolic acid on inhibiting tumor growth and enhancing the recovery of hematopoietic system postirradiation in mice. Cancer Lett. 1997, 111, 7-13. [CrossRef]

100. Zeng, G.; Chen, J.; Liang, Q.H.; You, W.H.; Wu, H.J.; Xiong, X.G. Ursolic acid inhibits T-cell activation through modulating nuclear factor-kB signaling. Chin. J. Integr. Med. 2012, 18, 34-39. [CrossRef] [PubMed]

101. Gayathri, R.; Priya, D.K.; Gunassekaran, G.R.; Sathisekaran, D. Ursolic acid attenuates oxidative stress-mediated hepatocellular carcinoma induction by diethylnitrosamine in male Wistar rats. Asian Pac. J. Cancer Prev. 2009, 10, 933-938. [PubMed]

102. Kowalczyk, M.C.; Walaszek, Z.; Kowalczyk, P.; Kinjo, T.; Hanausek, M.; Slaga, T.J. Differential effect of several phytochemicals and their derivatives on murine keratinocytes in vitro and in vivo: Implications for skin cancer prevention. Carcinogenesis 2009, 30, 1008-1015. [CrossRef] [PubMed]

103. Ohigashi, H.; Takamura, H.; Koshimizu, K.; Tokuda, H.; Ito, Y. Search of possible antitumor promoters by inhibition of 12-O-tetradecanoyphorbol-13-acetate-induced Epstein-Barr virus activation. Ursolic acid and oleanolic acid from an anti-inflammatory Chinese medicinal plant, Glechoma hederaceae L. Cancer Lett. 1986, 30, 143-151. [CrossRef]

104. Ito, H.; Kobayashi, E.; Li, S.; Hatano, T.; Sugita, D.; Kubo, N.; Shimura, S.; Itoh, Y.; Tokuda, H.; Nishino, H. Antitumor activity of compounds isolated from leaves of Eriobotrya japonica. J. Agric. Food Chem. 2002, 50, 2400-2403. [CrossRef] [PubMed]

105. Tokuda, H.; Ohigashi, H.; Koshimizu, K.; Ito, Y. Inhibitory effects of ursolic and oleanolic acid on skin tumor promotion by 12-O-tetradecanoyphorbol-13-acetate. Cancer Lett. 1986, 33, 279-285. [CrossRef]

106. McCubrey, J.A.; Steelman, L.S.; Abrams, S.L.; Lee, J.T.; Chang, F.; Bertrand, F.E.; Navolanic, P.M.; Terrian, D.M.; Franklin, R.A.; D'Assoro, A.B.; et al. Roles of the RAF /MEK/ERK and PI3K/PTEN/AKT pathways in malignant transformation and drug resistance. Adv. Enzym. Regul. 2006, 46, 249-279. [CrossRef] [PubMed]

107. Gilmore, T.D. Introduction to NF-кB: Players, pathways, perspectives. Oncogene 2006, 25, 6680-6684. [CrossRef] [PubMed]

108. Gemenetzidis, E.; Bose, A.; Riaz, A.M.; Chaplin, T.; Young, B.D.; Ali, M.; Sudgen, D.; Thurlow, J.K.; Cheong, S.C.; Teo, S.H.; et al. FOXM1 upregulation is an early event in human squamous cell carcinoma and it is enhanced by nicotine during malignant transformation. PLoS ONE 2009, 4, e4849. [CrossRef] [PubMed]

109. Wang, Z.; Ahmad, A.; Li, Y.; Benerjee, S.; Kong, D.; Sarkat, F.H. Forkhead box M1 transcription factor: A novel target for cancer therapy. Cancer Ther. Rev. 2010, 36, 151-156. [CrossRef] [PubMed]

110. Chao, D.T.; Korsmeyer, S.J. BCL-2 family: Regulators of cell death. Annu. Rev. Immunol. 1998, 16, $395-419$. [CrossRef] [PubMed]

111. Robertson, J.D.; Orrenius, S.; Zhivotovsky, B. Review: Nuclear events in apoptosis. J. Struct. Biol. 2000, 129, 346-358. [CrossRef] [PubMed] 
112. Nachmias, B.; Ashhab, Y.; Ben-Yehuda, D. The inhibitor of apoptosis protein family (IAPs): An emerging therapeutic target in cancer. Semin. Cancer Biol. 2004, 14, 231-243. [CrossRef] [PubMed]

113. Sciamanna, I.; Landriscina, M.; Pittoggi, C.; Quirino, M.; Mearelli, C.; Beraldi, R.; Mattei, E.; Serafino, A.; Cassano, A.; Sinibaldi-Vallebona, P.; et al. Inhibition of endogenous reverse transcriptase antagonizes human tumor growth. Oncogene 2005, 24, 3923-3931. [CrossRef] [PubMed]

114. Cárdenas, C.; Quesada, A.R.; Medina, M.A. Effects of ursolic acid on different steps of the angiogenic process. Biochem. Biophys. Res. Commun. 2004, 320, 402-408. [CrossRef] [PubMed]

115. Balkwill, F.; Mantovani, A. Inflammation and cancer: Back to Virchow? Lancet 2001, 357, $539-545$. [CrossRef]

116. Vane, J.R.; Bakhle, Y.S.; Botting, R.M. Cyclooxygenases 1 and 2. Annu. Rev. Pharmacol. Toxicol. 1998, 38, 97-120. [CrossRef] [PubMed]

117. Zhu, Z.; Qian, Z.; Yan, Z.; Zhao, C.; Wang, H.; Ying, G. A phase I pharmacokinetic study of ursolic acid nanoliposomes in healthy volunteers and patients with advanced solid tumors. Int. J. Nanomed. 2013, 8, 129-136.

118. Wang, X.H.; Zhou, S.Y.; Qian, Z.Z.; Zhang, H.L.; Qiu, L.H.; Song, Z.; Zhao, J.; Wang, P.; Hao, X.S.; Wang, H.Q. Evaluation of toxicity and single-dose pharmacokinetics of intravenous ursolic acid liposomes in healthy adult volunteers and patients with advanced solid tumors. Expert Opin. Drug Metab. Toxicol. 2013, 9, 117-125. [CrossRef] [PubMed]

119. Qian, Z.; Wang, X.; Song, Z.; Zhang, H.; Zhou, S.; Zhao, J.; Wang, H. A phase I trial to evaluate the multiple-dose safety and antitumor activity of ursolic acid liposomes in subjects with advanced solid tumors. Biomed. Res. Int. 2015, 2015. [CrossRef] [PubMed]

120. Saraswat, B.; Visen, P.K.S.; Agarwal, D.P. Ursolic acid isolated from Eucalyptus tereticornis protects against ethanol toxicity in isolated rat hepatocytes. Phytother. Res. 2000, 14, 163-166. [CrossRef]

121. Saravanan, R.; Pugalendi, V.; Pugalendi, K.V. Protective effect of ursolic acid on ethanol-mediated experimental liver damage in rats. Life Sci. 2006, 78, 713-718. [CrossRef] [PubMed]

122. Shukla, B.; Visen, P.K.S.; Patnaik, G.K.; Tripathi, S.C.; Srimal, R.C.; Dayal, R.; Dobhal, P.C. Hepatoprotective activity in the rat of ursolic acid isolated from Eucalyptus hybrid. Phytother. Res. 1992, 6, 74-79. [CrossRef]

123. Martin-Aragón, S.; de las Heras, B.; Sanchez-Reus, M.I.; Benedi, J. Pharmacological modification of endogenous antioxidant enzymes by ursolic acid on tetrachloride-induced liver damage in rats and primary cultures of rat hepatocytes. Exp. Toxicol. Pathol. 2001, 53, 199-206. [CrossRef] [PubMed]

124. Sundaresan, A.; Radhiga, T.; Pugalendi, K.V. Effect of ursolic acid and rosiglitazone combination on hepatic lipid accumulation in high fat diet-fed C57BL/6J mice. Eur. J. Pharmacol. 2014, 741, 297-303. [CrossRef] [PubMed]

125. Li, S.; Liao, X.; Meng, F.; Wang, Y.; Sun, Z.; Guo, F.; Li, X.; Meng, M.; Li, Y.; Sun, C. Therapeutic role of ursolic acid on ameliorating hepatic steatosis and improving metabolic disorders in high-fat diet-induced non-alcoholic fatty liver disease rats. PLoS ONE 2014, 29, e86724. [CrossRef] [PubMed]

126. Wang, X.; Ikejima, K.; Kon, K.; Arai, K.; Aoyama, T.; Okumura, K.; Abe, W.; Sato, N.; Watanabe, S. Ursolic acid ameliorates hepatic fibrosis in the rat by specific induction of apoptosis in hepatic stellate cells. J. Hepatol. 2011, 55, 379-387. [CrossRef] [PubMed]

127. Jin, Y.R.; Jin, J.L.; Li, C.H.; Piao, X.X.; Jin, N.G. Ursolic acid enhances mouse liver regeneration after partial hepatectomy. Pharm. Biol. 2012, 50, 523-528. [CrossRef] [PubMed]

128. Ness, A.R.; Powles, J.W. Fruit and vegetables, and cardiovascular disease: A review. Int. J. Epidemiol. 1997, 26, 1-13. [CrossRef] [PubMed]

129. Somova, L.O.; Nadar, A.; Rammanan, P.; Shode, F.O. Cardiovascular, antihyperlipidemic and antioxidant effects of oleanolic and ursolic acids in experimental hypertension. Phytomedicine 2003, 10, 115-121. [CrossRef] [PubMed]

130. Aguirre-Crespo, F.; Vergara-Galicia, J.; Villalobos-Molina, R.; López-Guerrero, J.J.; Navarette-Vázquez, G.; Estrada-Soto, S. Ursolic acid mediates the vasorelaxant activity of Lepechinia caulescens via NO release in isolated rat thoracic aorta. Life Sci. 2006, 79, 1062-1068. [CrossRef] [PubMed]

131. Rios, M.Y.; López-Martínez, S.; López-Vallejo, F.; Medina-Franco, J.L.; Villalobos-Molina, R.; Ibarra-Barajas, M.; Navarette-Vazquez, G.; Hidalgo-Figueroa, S.; Hernández-Abreu, O.; Estrada-Soto, S. Vasorelaxant activity of some structurally related triterpenic acids from Phoradendron reichenbachianum (Viscaceae) mainly by NO production: Ex vivo and in silico studies. Fitoterapia 2012, 83, 1023-1029. [CrossRef] [PubMed] 
132. Shimada, A.; Inagaki, M. Angiotensin I-converting enzyme (ACE) inhibitory activity of ursolic acid isolated from Thymus vulgaris L. Food Sci. Technol. Res. 2014, 3, 711-714. [CrossRef]

133. Senthil, S.; Sridevi, M.; Pugalendi, K.V. Protective effect of ursolic acid against myocardial ischemia induced by isoproterenol in rats. Toxicol. Mech. Methods 2007, 17, 57-65. [CrossRef] [PubMed]

134. Radhiga, T.; Rajamanickam, C.; Senthil, S.; Pugalendi, K.V. Effect of ursolic acid on cardiac marker enzymes, lipid profile and macroscopic enzyme mapping assay in isoproterenol-induced myocardial ischemic rats. Food Chem. Toxicol. 2012, 50, 3971-3977. [CrossRef] [PubMed]

135. Radhiga, T.; Rajamanickam, C.; Sundaresan, A.; Ezhumalai, M.; Pugalendi, K.V. Effect of ursolic acid treatment on apoptosis and DNA damage in isoproterenol-induced myocardial infarction. Biochimie 2012, 94, 1135-1142. [CrossRef] [PubMed]

136. Saravanan, R.; Pugalendi, V. Impact of ursolic acid on chronic ethanol-induced oxidative stress in the rat heart. Pharmacol. Rep. 2006, 58, 41-47. [PubMed]

137. Pozo, M.; Castilla, V.; Gutierrez, C.; de Nicolás, R.; Egido, J.; González-Cabrero, J. Ursolic acid inhibits neointima formation in the rat carotid artery injury model. Atherosclerosis 2006, 184, 53-62. [CrossRef] [PubMed]

138. Lv, Y.Y.; Jin, Y.; Han, G.Z.; Liu, Y.X.; Wu, T.; Liu, P.; Zhou, Q.; Liu, K.X.; Sun, H.J. Ursolic acid suppresses IL-6 induced C-reactive protein expression in HepG2 and protects HUVECs from injury induced by CRP. Eur. J. Pharm. Sci. 2012, 45, 190-194. [CrossRef] [PubMed]

139. Tannock, L.R. Ursolic acid on atherosclerosis: Apples and apples, or apples and oranges? Atherosclerosis 2011, 219, 397-398. [CrossRef] [PubMed]

140. Ullevig, S.L.; Zhao, Q.; Zamora, D.; Asmis, R. Ursolic acid protects diabetic mice against monocyte dysfunction and accelerated atherosclerosis. Atherosclerosis 2011, 219, 409-416. [CrossRef] [PubMed]

141. Messner, B.; Zeller, I.; Ploner, C.; Frotschnig, S.; Ringer, T.; Steinacher-Nigish, A.; Ritsch, A.; Laufer, G.; Huck, C.; Bernhard, D. Ursolic acid causes DNA-damage, P53-mediated, mitochondria- and caspase-dependent human endothelial cell apoptosis, and accelerates atherosclerotic plaque formation in vivo. Atherosclerosis 2011, 219, 402-408. [CrossRef] [PubMed]

142. Kim, M.; Han, C.H.; Lee, M.Y. Enhancement of platelet aggregation by ursolic acid and oleanolic acid. Biomol. Ther. 2014, 22, 254-259. [CrossRef] [PubMed]

143. Bondy, S.C.; LeBel, C.P. The relationship between excitotoxicity and oxidative stress in the central nervous system. Free Radic. Biol. Med. 1993, 14, 633-642. [CrossRef]

144. Shih, Y.H.; Chein, Y.C.; Wang, J.Y.; Fu, Y.S. Ursolic acid protects hippocampal neurons against kainate-induced excitotoxicity in rats. Neurosci. Lett. 2004, 362, 136-140. [CrossRef] [PubMed]

145. Lu, J.; Zheng, Y.L.; Wu, D.M.; Luo, L.; Sun, D.X.; Shan, Q. Ursolic acid ameliorates cognition deficits and attenuates oxidative damage in the brain of senescent mice induced by D-galactose. Biochem. Pharmacol. 2007, 74, 1078-1090. [CrossRef] [PubMed]

146. Lu, J.; Wu, D.M.; Zheng, Y.L.; Hu, B.; Zhang, Z.F.; Ye, Q.; Liu, C.M.; Shan, Q.; Wang, Y.L. Ursolic acid attenuates D-galactose-induced inflammatory response in mouse prefrontal cortex through inhibiting AGEs/RAGE/NF-kB pathway activation. Cereb. Cortex 2010, 20, 2540-2548. [CrossRef] [PubMed]

147. Wang, Y.J.; Lu, J.; Wu, D.M.; Zheng, Z.H.; Zheng, Y.L.; Wang, X.H.; Ruan, J.; Sun, X.; Shan, Q.; Zhang, Z.F. Ursolic acid attenuates lipopolysaccharide-induced cognitive deficits in mouse brain through suppressing p38/NF-кB mediated inflammatory pathways. Neurobiol. Learn. Mem. 2011, 96, 156-165. [CrossRef] [PubMed]

148. Li, L.; Zhang, X.; Cui, L.; Wang, L.; Liu, H.; Ji, H.; Du, Y. Ursolic acid promotes the neuroprotection by activating Nrf2 pathway after cerebral ischemia in mice. Brain Res. 2013, 1497, 32-39. [CrossRef] [PubMed]

149. Wu, D.M.; Lu, J.; Zhang, Y.Q.; Zheng, Y.L.; Hu, B.; Cheng, W.; Zhang, Z.F.; Li, M.Q. Ursolic acid improves domoic acid-induced cognitive deficits in mice. Toxicol. Appl. Pharmacol. 2013, 271, 127-136. [CrossRef] [PubMed]

150. Machado, D.G.; Neis, V.B.; Balen, G.O.; Colla, A.; Cunha, M.P.; Dalmarco, J.B.; Pizzolatti, M.G.; Prediger, R.D.; Rodrigues, A.L. Antidepressant-like effect of ursolic acid isolated from Rosmarinus officinalis L. in mice: Evidence of involvement of the dopaminergic system. Pharmacol. Biochem. Behav. 2012, 103, 204-211. [CrossRef] [PubMed] 
151. Colla, A.R.; Oliveira, A.; Pazini, F.L.; Rosa, J.M.; Manosso, L.M.; Cunha, M.P.; Rodrigues, A.L. Serotonergic and noradrenergic systems are implicated in the antidepressant-like effect of ursolic acid in mice. Pharmacol. Biochem. Behav. 2014, 124, 108-116. [CrossRef] [PubMed]

152. Colla, A.R.; Rosa, J.M.; Cunha, M.P.; Rodrigues, A.L. Anxiolytic-like effects of ursolic acid in mice. Eur. J. Pharmacol. 2015, 758, 171-176. [CrossRef] [PubMed]

153. Sakuma, K.; Yamaguchi, A. Novel intriguing strategies attenuating to sarcopenia. J. Aging Res. $2012,2012$. [CrossRef] [PubMed]

154. Kunkel, S.D.; Suneja, M.; Ebert, S.M.; Bongers, K.S.; Fox, D.K.; Malmberg, S.E.; Alipour, F.; Shields, R.K.; Adams, C.M. mRNA expression signatures of human skeletal muscle atrophy identify a natural compound that increases muscle mass. Cell Metab. 2011, 13, 627-638. [CrossRef] [PubMed]

155. Kunkel, S.D.; Elmore, C.J.; Bongers, K.S.; Ebert, S.M.; Fox, D.K.; Dyle, M.C.; Bullard, S.A.; Adams, C.M. Ursolic acid increases skeletal muscle and brown fat and decreases diet-induced obesity, glucose intolerance and fatty liver disease. PLoS ONE 2012, 7, e39332. [CrossRef] [PubMed]

156. Bakhtiari, N.; Hosseinkhani, S.; Tashakor, A.; Hemmati, R. Ursolic acid ameliorates aging-metabolic phenotype through promoting of skeletal muscle rejuvenation. Med. Hypotheses 2015, 85, 1-6. [CrossRef] [PubMed]

157. Bang, H.S.; Seo, D.Y.; Chung, Y.M.; Oh, K.M.; Park, J.J.; Arturo, F.; Jeong, H.S.; Kim, N.; Han, J. Ursolic acid-induced elevation of serum irisin augments muscle strength during resistance training in men. Korean J. Physiol. Pharmacol. 2014, 18, 441-446. [CrossRef] [PubMed]

158. Raggatt, L.J.; Partridge, N.C. Cellular and molecular mechanisms of bone remodeling. J. Biol. Chem. 2010, 285, 25103-25108. [CrossRef] [PubMed]

159. Manolagas, S.C. Birth and death of bone cells: Basic regulatory mechanisms and implications for the pathogenesis and treatment of osteoporosis. Endocr. Rev. 2000, 21, 115-137. [CrossRef] [PubMed]

160. Lee, S.U.; Park, S.J.; Kwak, H.B.; Oh, J.; Min, Y.K.; Kim, S.H. Anabolic activity of ursolic acid in bone: Stimulating osteoblast differentiation in vitro and inducing new bone formation in vivo. Pharmacol. Res. 2008, 58, 290-296. [CrossRef] [PubMed]

161. Tan, H.; Furuta, S.; Nagata, T.; Ohnuki, K.; Akasaka, T.; Shirouchi, B.; Sato, M.; Kondo, R.; Shimizu, K. Inhibitory effect of the leaves of loquat (Eriobotrya japonica) on bone mineral density loss in ovariectomized mice and osteoclast differentiation. J. Agric. Food Chem. 2014, 62, 836-841. [CrossRef] [PubMed]

162. Tan, H.; Ashour, A.; Katakura, Y.; Shimizu, K. A structure-activity relationship study on antiosteoclastogenesis effect of triterpenoids from leaves of loquat (Eriobotrya japonica). Phytomedicine 2015, 22, 498-503. [CrossRef] [PubMed]

163. Jiang, C.; Xiao, F.; Gu, X.; Zhai, Z.; Liu, X.; Wang, W.; Tang, T.; Wang, Y.; Zhu, Z.; Dai, K.; et al. Inhibitory effects of ursolic acid on osteoclastogenesis and titanium particle-induced osteolysis are mediated primarily via suppression of NF-kB signaling. Biochimie 2015, 111, 107-118. [CrossRef] [PubMed]

164. Yu, S.G.; Zhang, C.J.; Xu, X.E.; Sun, J.H.; Zhang, L.; Yu, P.F. Ursolic acid derivative ameliorates streptozotocin-induced diabestic bone deleterious effect in mice. Int. J. Clin. Exp. Pathol. 2015, 8, 3681-3690. [PubMed]

165. Fu, H.J.; Zhou, Y.R.; Bao, B.H.; Jia, M.X.; Zhao, Y.; Zhang, L.; Li, J.X.; He, H.L.; Zhou, X.M. Tryptophan hydroxylase 1 (Tph-1)-targeted bone anabolic agents for osteoporosis. J. Med. Chem. 2014, 57, 4692-4709. [CrossRef] [PubMed]

166. Both, D.M.; Goodtzova, K.; Yarosh, D.B.; Brown, D.A. Liposome-encapsulated ursolic acid increases ceramides and collagen in human skin cells. Arch. Derm. Res. 2002, 293, 569-575. [CrossRef] [PubMed]

167. Wójciak-Kosior, M.; Paduch, R.; Matysik-Woźniak, A.; Niedziela, P.; Donica, H. The effect of ursolic and oleanolic acids on human skin fibroblast cells. Folia Hystochem. Cytobiol. 2011, 49, 664-669. [CrossRef]

168. Ding, Y.J.; Sun, C.Y.; Wen, C.C.; Chen, Y.H. Nephroprotective role of resveratrol and ursolic acid in aristolochic acid intoxicated zebrafish. Toxins 2015, 7, 97-109. [CrossRef] [PubMed]

169. Pai, P.G.; Chamari Nawarathna, S.; Kulkarni, A.; Habeeba, U.; Reddy, S.C.; Teerthanath, S.; Shenoy, J.P. Nephroprotective effect of ursolic acid in a murine model of gentamicin-induced renal damage. ISRN Pharmacol. 2012, 2012. [CrossRef] [PubMed]

170. Chen, X.; Wan, Y.; Zhou, T.; Li, J.; Wei, Y. Ursolic acid attenuates lipopolysaccharide-induced acute lung injury in a mouse model. Immunotherapy 2013, 5, 39-47. [CrossRef] [PubMed] 
171. Do Nascimento, P.G.; Lemos, T.L.; Bizerra, A.M.; Arriaga, Â.M.; Ferreira, D.A.; Santiago, G.M.; Braz-Filho, R.; Costa, J.G. Antibacterial and antioxidant activities of ursolic acid and derivatives. Molecules 2014, 19, 1317-1327. [CrossRef] [PubMed]

172. Cunha, W.R.; de Matos, G.X.; Souza, M.G.; Tozatti, M.G.; Andrade e Silva, M.L.; Martins, C.H.; da Silva, R.; da Silva Filho, A.A. Evaluation of the antibacterial activity of the methylene chloride extract of Miconia ligustroides, isolated triterpene acids, and ursolic acid derivatives. Pharm. Biol. 2010, 48, 166-169. [CrossRef] [PubMed]

173. Mallavadhani, U.V.; Mahapatra, A.; Jamil, K.; Reddy, P.S. Antimicrobial activity of some pentacyclic triterpenes and their synthesized 3-O-lipophilic chains. Biol. Pharm. Bull. 2004, 27, 1576-1579. [CrossRef] [PubMed]

174. Hu, Z.; Gu, Z.; Sun, M.; Zhang, K.; Gao, P.; Yang, Q.; Yuan, Y. Ursolic acid improves survival and attenuates lung injury in septic rats induced by cecal ligation and puncture. J. Surg. Res. 2015, 194, 528-536. [CrossRef] [PubMed]

175. Kurek, A.; Grudniak, A.M.; Szwed, M.; Klicka, A.; Samluk, L.; Wolska, K.I.; Janiszowska, W.; Popowska, M. Oleanolic acid and ursolic acid effect peptidoglycan metabolism in Listeria monocytogenes. Antonie Van Leeuwenhoek 2010, 97, 61-68. [CrossRef] [PubMed]

176. Huang, L.; Luo, H.; Li, Q.; Wang, D.; Zhang, J.; Hao, X.; Yang, X. Pentacyclic triterpene derivatives possessing polyhydroxyl ring A inhibit Gram-positive bacteria growth by regulating metabolism and virulence genes expression. Eur. J. Med. Chem. 2015, 95, 64-75. [CrossRef] [PubMed]

177. Fontanay, S.; Grare, M.; Mayer, J.; Finance, C.; Duval, R.E. Ursolic, oleanolic and betulinic acids: Antibacterial spectra and selectivity indexes. J. Ethnopharmacol. 2008, 120, 272-276. [CrossRef] [PubMed]

178. Kurek, A.; Nadkowska, P.; Pliszka, S.; Wolska, K.I. Modulation of antibiotic resistance in bacterial pathogens by oleanolic acid and ursolic acid. Phytomedicine 2012, 19, 515-519. [CrossRef] [PubMed]

179. Woldemichael, G.M.; Franzblau, S.G.; Zhang, F.; Wang, Y.; Timmermann, B.N. Inhibitory effect of sterols from Ruprechtia triflora and diterpenes from Calceolaria pinnifolia on the growth of Mycobacterium tuberculosis. Planta Med. 2003, 69, 628-631. [PubMed]

180. Jiménez, A.; Meckes, M.; Alvarez, V.; Torres, J.; Parra, R. Secondary metabolites from Chamaedora tepejilote (Palmae) are active against Mycobacterium tuberculosis. Phytother. Res. 2005, 19, 320-322. [CrossRef] [PubMed]

181. Jiménez-Arellanes, A.; Luna-Herrera, J.; Cornejo-Garrido, J.; López-Garcia, S.; Castro-Mussot, M.E.; Meckes-Fisher, M.; Mata-Espinosa, D.; Marquina, B.; Torres, J.; Hernández-Pando, R. Ursolic and oleanolic acids as antimicrobial and immunomodulatory compounds for tuberculosis treatment. BMC Complement. Altern. Med. 2013, 13, 258-269. [CrossRef] [PubMed]

182. Kim, S.G.; Kim, M.J.; Jin, D.; Park, S.N.; Cho, E.; Freire, M.O.; Jang, S.J.; Park, Y.J.; Kook, J.K. Antimicrobial effect of ursolic acid and oleanolic acid against methicillin-resistant Staphylococcus aureus. Korean J. Microbiol. 2012, 48, 212-215. [CrossRef]

183. Horiuchi, K.; Shiota, S.; Hatano, T.; Yoshida, T.; Kuroda, T.; Tsuchiya, T. Antimicrobial activity of oleanolic acid from Salvia officinalis and related compounds on vancomycin-resistant enterococci (VRE). Biol. Pharm. Bull. 2007, 30, 1147-1149. [CrossRef] [PubMed]

184. Chung, P.Y.; Navaratnam, P.; Chung, L.Y. Synergistic antimicrobial activity between pentacyclic triterpenoids and antibiotics against Staphylococcus aureus strains. Ann. Clin. Microbiol. Antimicrob. 2011, 10, 25. [CrossRef] [PubMed]

185. Kozai, K.; Miyake, Y.; Kohda, H.; Kametaka, S.; Yamasaki, K.; Suginaka, H.; Nagasaka, N. Inhibition of glucosyltransferase form Streptococcus mutans by oleanolic acid and ursolic acid. Caries Res. 1987, 21, 104-108. [CrossRef] [PubMed]

186. Kim, M.J.; Kim, C.S.; Park, J.Y.; Lim, Y.K.; Park, S.N.; Ahn, S.J.; Jin, D.C.; Kim, T.H.; Kook, J.K. Antimicrobial effects of ursolic acid against mutans Streptococci isolated from Koreans. Int. J. Oral Biol. 2011, 36, 7-11.

187. Kim, S.; Song, M.; Roh, B.D.; Park, S.H.; Park, J.W. Inhibition of Streptococcus mutans biofilm formation on composite resins containing ursolic acid. Restor. Dent. Endod. 2013, 38, 65-72. [CrossRef] [PubMed]

188. Filho, J.R.; de Sousa Falcão, H.; Batista, L.M.; Filho, J.M.; Piuvezam, M.R. Effects of plant extract on HIV-1 protease. Curr. HIV Res. 2010, 8, 531-544. [CrossRef] [PubMed]

189. Hattori, M.; Ma, C.M.; Wei, Y.; Salah El Dine, R.; Sato, N. Survey of Anti-HIV and Anti-HCV compounds from natural sources. Can. Chem. Tran. 2013, 1, 116-140. 
190. Kashiwada, Y.; Wang, H.K.; Nagao, T.; Kitanaka, S.; Yasuda, I.; Fujioka, T.; Yamagishi, T.; Cosentino, L.M.; Kozuka, M.; Okabe, H.; et al. Anti-AIDS agents. 30. Anti-HIV activity of oleanolic acid, pomolic acid, and structurally related triterpenoids. J. Nat. Prod. 1998, 61, 1090-1095. [CrossRef] [PubMed]

191. Ma, C.M.; Nakamura, N.; Miyashiro, H.; Hattori, M.; Shimotohno, K. Inhibitory effect of constituents from Cynomorium songaricum and related triterpene derivatives on HIV-1 protease. Chem. Pharm. Bull. 1999, 47, 141-145. [CrossRef] [PubMed]

192. Quéré, L.; Wenger, T.; Schramm, H.J. Triterpenes as potential dimerization inhibitors of HIV-1 protease. Biochem. Biophys. Res. Commun. 1996, 227, 484-488. [CrossRef] [PubMed]

193. Kong, L.; Li, S.; Liao, Q.; Zhang, Y.; Sun, R.; Zhu, X.; Zhang, Q.; Wang, J.; Wu, X.; Fang, X.; et al. Oleanolic acid and ursolic acid: Novel hepatitis C virus antivirals that inhibit NS5B activity. Antivir. Res. 2013, 98, 44-53. [CrossRef] [PubMed]

194. Garcia-Risco, M.R.; Vázquez, E.; Sheldon, J.; Steinmann, E.; Riebesehl, N.; Fornari, T.; Reglero, G. Supercritical fluid extraction of heather (Calluna vulgaris) and evaluation of anti-hepatitis C virus activity of the extracts. Virus Res. 2015, 198, 9-14. [CrossRef] [PubMed]

195. Bag, P.; Chattopadhyay, D.; Mukherjee, H.; Ojha, D.; Mandal, N.; Sarkar, M.C.; Chatterjee, T.; Das, G.; Chakraborti, S. Anti-herpes virus activities of bioactive fraction and isolated pure constituents of Mallotus peltatus an ethnomedicine from Andaman Islands. Virol. J. 2012, 9, 98-109. [CrossRef] [PubMed]

196. Yamamoto, E.S.; Campos, B.L.S.; Laurenti, M.D.; Lago, J.H.G.; dos Santos Grecco, S.; Corbett, C.E.P.; Passero, L.F.D. Treatment with triterpenic fraction purified from Baccharis uncinella leaves inhibits Leishmania (Leishmania) amazonensis spreading and improves Th1 immune response in infected mice. Parasitol. Res. 2014, 113, 333-339. [CrossRef] [PubMed]

197. Van Baren, C.; Anao, I.; Leo Di Lira, P.; Debenedetti, S.; Houghton, P.; Croft, S.; Martino, V. Triterpenic acids and flavonoids from Satureja parvifolia. Evaluation of their antiprotozoal activity. Z. Naturforschung C. 2006, 61, 189-192. [CrossRef]

198. Innocente, A.; Silva, G.N.; Cruz, L.N.; Moraes, M.S.; Nakabashi, M.; Sonnet, P.; Gosmann, G.; Garcia, C.R.; Gnoatto, S.C. Synthesis and antiplasmodial activity of betulinic and ursolic analogues. Molecules 2012, 17, 12003-12014. [CrossRef] [PubMed]

199. Della-Vechia, L.; Dassonville-Klimpt, A.; Grellier, P.; Sonnet, P.; Gosmann, G.; Gnoatto, S.C.B. The Beckmann rearrangement applied to ursolic acid with antimalarial activity in medicinal chemistry studies. Lett. Org. Chem. 2012, 9, 92-95. [CrossRef]

200. Cimanga, R.K.; Tona, G.L.; Mesia, G.K.; Kambu, O.K.; Bakana, D.P.; Kalenda, P.D.T.; Penge, A.O.; Muyembe, J.J.T.; Totté, J.; Pieters, L.; et al. Bioassay-guided isolation of antimalarial triterpenoid acids from the leaves of Morinda lucida. Pharm. Biol. 2006, 44, 677-681. [CrossRef]

201. Da Silva Ferreira, D.; Esperandim, V.R.; Toldo, M.P.; Kuehn, C.C.; do Prado Júnior, J.C.; Cunha, W.R.; e Silva, M.L.; de Albuquerque, S. In vivo activity of ursolic and oleanolic acid during the acute phase of Trypanosoma cruzi infection. Exp. Parasitol. 2013, 134, 455-459. [CrossRef] [PubMed]

202. Innocente, A.; Casanova, B.B.; Klein, F.; Lana, A.D.; Pereira, D.; Muniz, M.N.; Sonnet, P.; Gosmann, G.; Fuentefria, A.M.; Gnoatto, S.C.B. Synthesis of isosteric triterpenoid derivatives and antifungal activity. Chem. Biol. Drug Des. 2014, 83, 344-349. [CrossRef] [PubMed]

203. Saini, P.; Gayen, P.; Kumar, D.; Nayak, A.; Mukherjee, N.; Mukherjee, S.; Pal, B.C.; Sinha Babu, S.P. Antifilarial effect of ursolic acid from Nyctanthes arbortristis: Molecular and biochemical evidences. Parasitol. Int. 2014, 63, 717-728. [CrossRef] [PubMed]

204. Feng, Z.; Wu, C.; Zhou, X.; Wu, F.; Li, J.; Li, T.; Yin, Y. Disturbance of the intestinal microbial community by ursolic acid contributes to its function as a regulator of fat deposition. J. Funct. Foods 2015, 14, 456-468. [CrossRef]

(C) 2015 by the authors; licensee MDPI, Basel, Switzerland. This article is an open access article distributed under the terms and conditions of the Creative Commons by Attribution (CC-BY) license (http:/ / creativecommons.org/licenses/by/4.0/). 